\title{
Evaluation of electrochromic windows impact in the energy performance of buildings in Mediterranean climates
}

\author{
P.F. Tavares ${ }^{\mathrm{a}, \mathrm{b}, \mathrm{c}, *}$, A.R. Gaspar ${ }^{\mathrm{c}}$, A.G. Martins ${ }^{\mathrm{b}, \mathrm{d}}$, F. Frontini ${ }^{\mathrm{e}}$ \\ ${ }^{a}$ Coimbra Institute of Engineering, Polytechnic Institute of Coimbra, Electrical Engineering Department, Rua Pedro Nunes, Quinta da Nora, $3030-199$ \\ Coimbra, Portugal \\ ${ }^{\mathrm{b}}$ INESC Coimbra, Institute for Systems Engineering and Computers at Coimbra, Rua Antero de Quental, No. 199, $3000-033$ Coimbra, Portugal \\ c ADAI-LAETA - Department of Mechanical Engineering, University of Coimbra, Rua Luis Reis Santos, Pólo II, 3030-788 Coimbra, Portugal \\ ${ }^{\mathrm{d}}$ Faculty of Science and Technology, University of Coimbra, Portugal, Electrical Engineering Department, Pólo 2 da UC, Pinhal de Marrocos, 3030-290 \\ Coimbra, Portugal \\ e Institute for Applied Sustainability to the Built Environment (ISAAC), University for Applied Sciences of Southern Switzerland (SUPSI), Via Trevano CH, \\ 6952 Canobbio, Switzerland
}

\section{H I G H L I G H T S}

- Energy performance analysis of Electrochromic (EC) windows is carried out.

- EC glass and control strategies are modeled and implemented in ESP-r.

- EC windows are evaluated, on a test prototype, as an alternative to shading devices.

- Set-points and measured variables are used to control optical properties of EC glass.

- The most effective results are obtained when EC windows are used in the west façade.

\section{A R T I C L E I N F O}

Article history:

Received 31 December 2012

Accepted 5 July 2013

Available online 12 August 2013

Keywords:

Electrochromic windows

Building thermal performance

Control of solar gains

\begin{abstract}
A B S T R A C T
Old buildings refurbishment is essential for the global improvement of building energy indicators. Within this context, the paper focuses on the energy savings that may occur when using electrochromic (EC) windows, an interesting emerging technology alternative to shading devices to control solar gain in buildings located in Mediterranean climates. The EC windows technology is briefly presented and the optical properties adjustments of the glasses are discussed according to the operated range. The EC window dynamic behavior and the different control strategies are modeled and implemented in the ESP-r building simulation program. The EC window impact in the energy needs for heating and cooling is studied, considering different ambient parameters (exterior dry bulb temperature, interior dry bulb temperature and incident radiation) and set points for the EC control. A comparison of several windows solutions (single, double-glazing and EC windows), the type of building, internal gains from occupancy, lighting and equipment and the orientation of windows are considered for discussion through the analysis of the energy needs for heating and cooling. It is concluded that for this climate the best positive results are obtained when the EC are used in the west façade. For the south façade the results show no significant advantages in using EC windows.
\end{abstract}

(c) 2013 Elsevier Ltd. All rights reserved.

\section{Introduction}

In buildings refurbishment it is necessary to consider three fundamental objectives: to maintain the existing building stock adapting the infrastructures to support the actual economic activity

\footnotetext{
* Corresponding author at: Coimbra Institute of Engineering, Polytechnic Institute of Coimbra, Electrical Engineering Department, Rua Pedro Nunes, Quinta da Nora, 3030-199 Coimbra, Portugal. Tel.:+351 239790 200x3210; fax:+351 239790201.

E-mail addresses: ptavares@inescc.pt, ptavares@isec.pt (P.F. Tavares), adelio.gaspar@dem.uc.pt (A.R. Gaspar), amartins@deec.uc.pt (A.G. Martins), francesco.frontini@supsi.ch (F. Frontini).
}

and ensure adequate living standards, protect the environment, safeguarding the historical architecture. From the energy point of view the main purpose of rehabilitation is to obtain rehabilitated buildings as closely as possible to the low energy buildings (Santamouris and Dascalaki, 2002).

In Portugal, buildings to be refurbished have typically single clear glazing. They are commonly replaced by double clear (typical glass used in Portugal, without improved properties, usually known as "current glass" or "conventional glass") and, less frequently, glazing with improved optical characteristics to reduce the solar gains. Therefore, glazing with climate adaptive optical properties may play an important function in the optimization of 
the annual solar gains in order to maximize the gains during winter, preventing the situation of overheating and limiting the solar gains during the summer periods.

In contemporary architecture glass facades have always aroused great interest (Azens and Granqvist, 2003). The architects always wants to have windows and glazed facades with increasing capacities of controlling the amount of light and heat transmitted to the interior of buildings. The glasses that allow this control are designated by chromogenic (Granqvist, 2006a, 2006b). The windows whose optical properties can be regulated in architecture can be considered as "high technology" (Granqvist et al. 2007).

The high performance windows can make use of a variety of chromogenic technologies, wherein the chromogenic term is used to indicate that optical properties can be changed in response to an external stimulus (Granqvist et al., 2010).

The main chromogenic technologies are: electrochromics (EC) (depending on the application of a voltage or electric charge), the termochromics (TC) (depending on temperature), photochromics (dependent on light irradiation, usually in the ultraviolet range), and gasochromics (depending on exposure to reducing or oxidizing gases) (Carmody et al., 2004; Granqvist, 2006a; Granqvist et al., 2009, 2010). It is possible to have more than one of these technologies in the same glass (Granqvist et al., 2010).

The electrochromism can be defined as a reversible change in the optical properties of a material induced by oxidation (loss of electrons) and reduction (gain of electrons) electrochemical due to the passage of an electric current by applying a potential difference between two electrodes (Somani and Radhakrishnan, 2002; Rowley and Mortimer, 2002; Stenzel et al. 2003; Mortimer et al. 2006). This change of the optical properties is reversible, that is, it can always go back to any one state, and lasting (Granqvist, 2012).

This phenomenon allows regulating the transmissivity $(\tau)$, the reflectivity $(\rho)$, the absorptivity $(\alpha)$ and emissivity $(\varepsilon)$ between two extreme values (Granqvist et al. 2003; Granqvist, 2005). As such, one can define the EC windows as a technology that utilizes an electrical voltage for controlling the amount of light passing through the glass (Sottile, 2002).

The EC technology involves the interaction of basic physics and chemistry, thin film science, device technology, and market opportunities (Granqvist, 2000). There are EC windows that need constant power to maintain a state and EC windows that have memory effect and thus only require power to promote a transition. For the EC with memory effect energy is needed only on an impulse basis to force the transition of the EC window to a different state (Granqvist, 2006b; Kraft and Rottmann, 2006, 2009). These EC windows operate on a "battery-like" mode, with a construction process similar to the laminated glasses made of five layers (Häusler et al., 2004; Kraft et al., 2006; Granqvist et al., 2010). The five layers are illustrated in Fig. 1 (Granqvist, 2000; Lee and DiBartolomeo, 2002; Avendaño et al., 2006; Granqvist et al., 2010).

Layer 1: glass or plastic coated with a transparent conductor (usually FTO-fluorine-doped tin oxide or ITO-tin-doped indium oxide);

Layer 2: one or more electro-active cathodic layers (usually tungsten trioxide $\mathrm{WO}_{3}$ );

Layer 3: ion conductor layer-electrolyte (usually PVB-polyvinyl butyral);

Layer 4: ion storage film or one or more electro-active anodic layers (usually Prussian blue, an inorganic material)-sometimes it is called the counter electrode; and

Layer 5: transparent conductor coating glass or plastic.

The DC voltage needed to change the optical properties of the window is low, typically between 0 and $5 \mathrm{~V}$ (Fasano et al., 2002). The process is continuous (it is possible to fix at any state

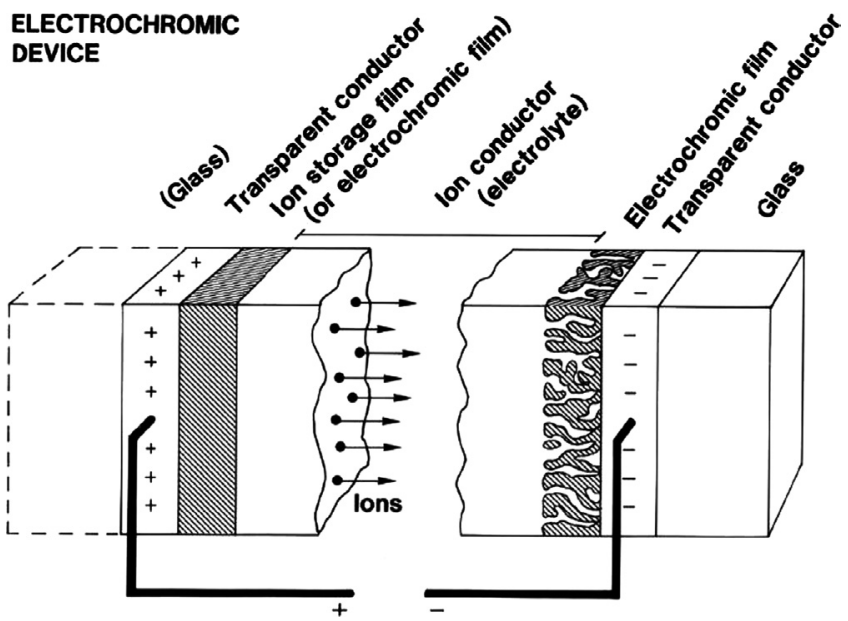

Fig. 1. Schematic representation of an EC device showing the ions displacement under an externally-applied electric field (Avendaño et al., 2006; Granqvist, 2006b).

condition) and reversible through a simple inversion of the electrical polarity (Lee et al., 2004). The transition process velocity decreases with the increase of the ambient temperature and a complete cycle from fully bleached to fully colored is slower than the reversed process. For a window with approximately $1 \mathrm{~m}^{2}$ it takes $12 \mathrm{~min}$ to fully color and $8 \mathrm{~min}$ to fully bleach.

The potential of energy saving in buildings for the use of this technology depends on the location, type of building, orientation, lighting and comfort demands. The energy efficiency increases the more the location is sunnier and warmer (Karlsson, 2001).

Although there are several manufacturers worldwide for electrochromic glass, only three have commercially available products in various dimensions (Baetens et al., 2010): SAGE Electrochromics Inc. ${ }^{\mathrm{TM}}$ from USA, Gesimat $\mathrm{GmbH}^{\mathrm{TM}}$ and EControl-Glas ${ }^{\mathrm{TM}}$, both from Germany.

According to their durability tests, of about 50,000 cycles, and admitting under normal conditions five cycles per day, all manufacturers indicate that the duration of these windows is between 20 and 30 years.

The study developed in this paper considers the application of EC technology that has memory effect. A comparison of the influence of three types of glazing (single, double and electrochromic) in terms of energy savings with respect to heating and cooling is performed in order to evaluate the usefulness of the EC technology in the energy efficiency of buildings. The energy analysis performed was based on achieving the heating, cooling and annual energy requirements.

\section{Methodology}

Using the energy performance simulation of building the present paper is focused in the analysis of:

- Different types of window glass technologies: single (SG) and double (DGU) glass with static optical properties; double glass with dynamic optical properties-electrochromic (EC) glass;

- various types of EC glass control (solar radiation, outdoor air temperature and indoor air temperature) and different thresholds for state transition;

- different facade orientations of the window location (east, south and west); and

- the effect of the glass area and the influence of the air infiltration rate to consider the increase of the frames tightness in the rehabilitation context. 
The objective is to understand how the energy consumption of the spaces will be modified when the building envelope becomes less permeable and how the controlled EC glass can contribute to the energy efficiency of buildings, particularly in the rehabilitation context.

\subsection{Simulator}

For the present study the ESP-r version 11.10 for Linux ${ }^{\mathrm{TM}}$ (Crawley et al., 2005a, 2005b, 2008) was used as the program to perform energy performance simulations. The ESP-r is an energy simulation program on a permanent basis, able to model phenomena involving exchanges of energy and mass inside buildings as well as other auxiliary systems. It also allows simulating real conditions in a building, analyzing its performance in terms of energy consumption, occupant comfort indices, evolution of temperature, air quality, control systems, etc. The ESP-r is a computer program (simulator) available at no cost under an open source license (Open Source), developed by the "Energy Systems Research Unit" (ESRU), University of Strathclyde, Scotland.

The simulators fundamentals (modules, mathematical description, models, etc.) in general and in particular for ESP-r can be found in Clarke (2001). The way the shaders and electrochromic windows could be implemented in ESP-r was based on Strachan (1990) and Haugaard (2003).

\subsection{Building test cell model}

To perform the simulations a model of a square floor area corresponding to a typical scholar building built during the fifties of the past century was defined.

Three identical blocks were defined (vd. Fig. 2), which differ only in the type of window glass. The main characteristics are:

test cells dimensions $(W \times D \times H): 7 \mathrm{~m} \times 7 \mathrm{~m} \times 4 \mathrm{~m}$;

exterior walls characteristics: limestone coated with plaster with $60 \mathrm{~cm}$ of thickness $\left[U_{\text {value }}=1.90 \mathrm{~W} /\left(\mathrm{m}^{2} \mathrm{~K}\right)\right]$;

ceiling and floor characteristics: typical mid-floor construction (plaster, concrete and wood) with $15 \mathrm{~cm}$ of thickness $\left[U_{\text {value }}=2.62 \mathrm{~W} /\left(\mathrm{m}^{2} \mathrm{~K}\right)\right]$; similar boundary conditions (it is admitted during the simulation process that a thermal zone with identical environmental thermal conditions is adjacent to the simulated thermal zone; Clarke, 2001), considering that it is adjacent to another thermal zone;

window dimensions $(W \times H): 3.0 \mathrm{~m} \times 1.8 \mathrm{~m}$, placed $1 \mathrm{~m}$ from the floor and centered on the façade; and

outside air infiltration: a constant value of $0.6 \mathrm{~h}^{-1}$.

In literature (Rauh, 1999; Syrrakou et al., 2005; Syrrakou et al., 2006; Papaefthimiou et al., 2006a; Papaefthimiou et al., 2006b; Assimakopoulos et al., 2007; Kraft and Rottmann, 2009; Piccolo et al., 2009) it is usual to develop these types of analysis using prototype glasses, not commercially available.

For the present study the data were chosen from SAGETM, since this manufacturer provides the necessary detailed optical properties needed for the simulation. The optical properties of the three studied glass types (single, double and double EC) are listed in Table 1. The data for EC glass corresponds to a laminated type glass and an air gap with $12.7 \mathrm{~mm}$ (0.5 in.) filled with air and argon (90\%).

As an example, Fig. 2 shows a picture of the model in ESP-r with the glazing area oriented east. The spacing between blocks was set to avoid shadowing between test cells. One test cell is parameterized with single glazing, another with double glazing and another with double EC glazing. Another ESP-r model with the facade entirely glazed (glass area of $25.84 \mathrm{~m}^{2}$ ) was defined in order to study the influence of the glass area in the energy performance of the model.

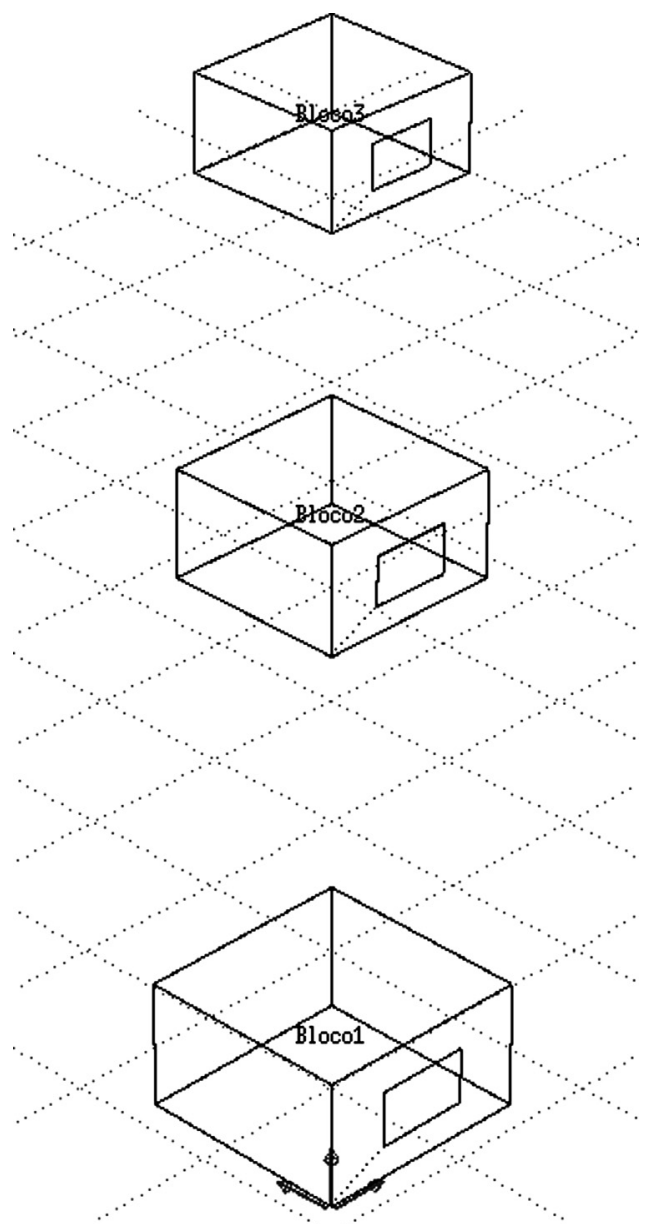

Fig. 2. Example of ESP-r model, with the three test cells and windows in east facade.

Table 1

Physical properties of the three types of glasses analyzed.

\begin{tabular}{lllll}
\hline Properties & $\begin{array}{l}\text { Single } \\
\text { Clear } 3 \mathrm{~mm}\end{array}$ & $\begin{array}{l}\text { Double } \\
\text { Clear }(4 \mathrm{~mm} / 12 \mathrm{~mm} / 4 \mathrm{~mm})\end{array}$ & $\begin{array}{l}\text { Double EC } \\
\text { SAGETM } \\
(4 \mathrm{~mm} / 12 \mathrm{~mm} / 4 \mathrm{~mm})\end{array}$ \\
\cline { 4 - 5 } & & & Clear & Colored \\
\hline$U\left(\mathrm{~W} /\left(\mathrm{m}^{2} \mathrm{~K}\right)\right.$ & 5.79 & 2.80 & 1.60 & 1.60 \\
$g_{\perp}$ & 0.86 & 0.75 & 0.48 & 0.090 \\
$\rho_{\text {solar, } \perp}$ & 0.07 & 0.12 & 0.20 & 0.100 \\
$\tau_{\text {solar }, \perp}$ & 0.82 & 0.67 & 0.40 & 0.015 \\
$\alpha_{\text {solar }, \perp}$ & 0.11 & 0.21 & 0.40 & 0.885 \\
$\tau_{v, \perp}$ & 0.89 & 0.80 & 0.62 & 0.035 \\
\hline
\end{tabular}

The diagrams of occupancy, lighting and equipment were estimated based on the results of an energy audit performed on the building considered, which permitted to estimate the energy consumption breakdown. These diagrams are presented in Figs. 3 and 4. During Sunday, it was not considered occupancy but was considered a constant value of $1 \%$ for lighting and equipment.

From the energy audit walk-through and equipments and systems characterization, the maximum values for occupancy, lighting and equipment were estimated and considered for the simulation: 


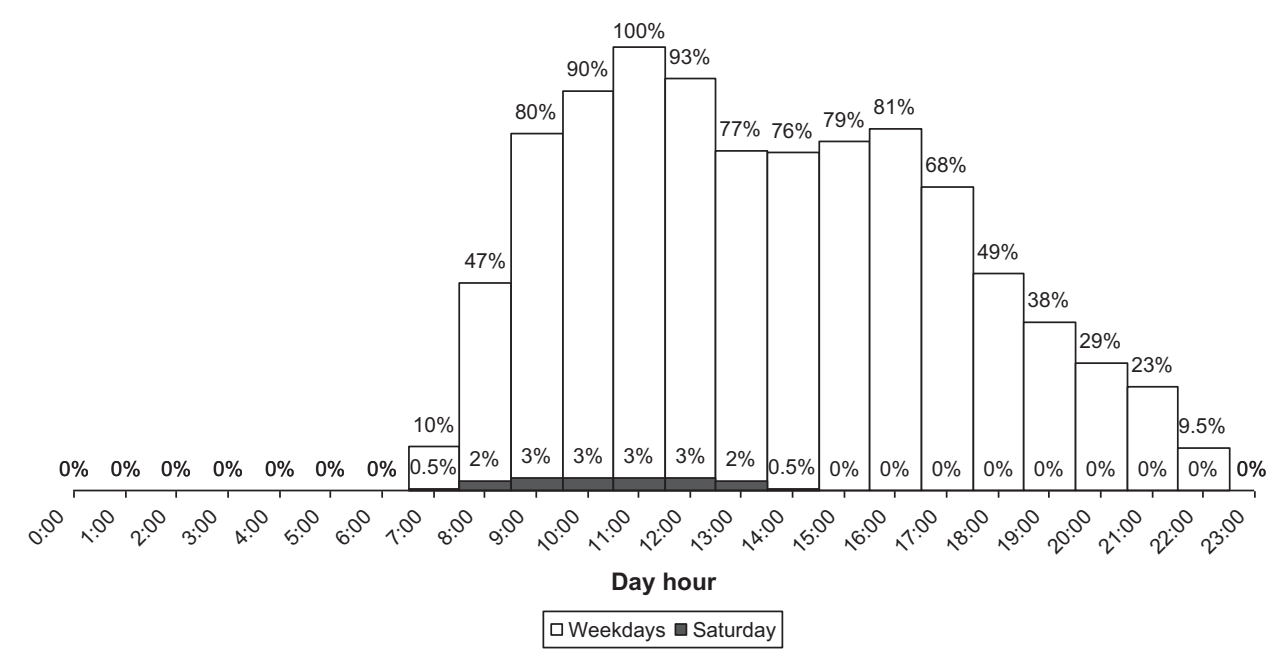

Fig. 3. Occupancy diagrams for weekdays and Saturday.

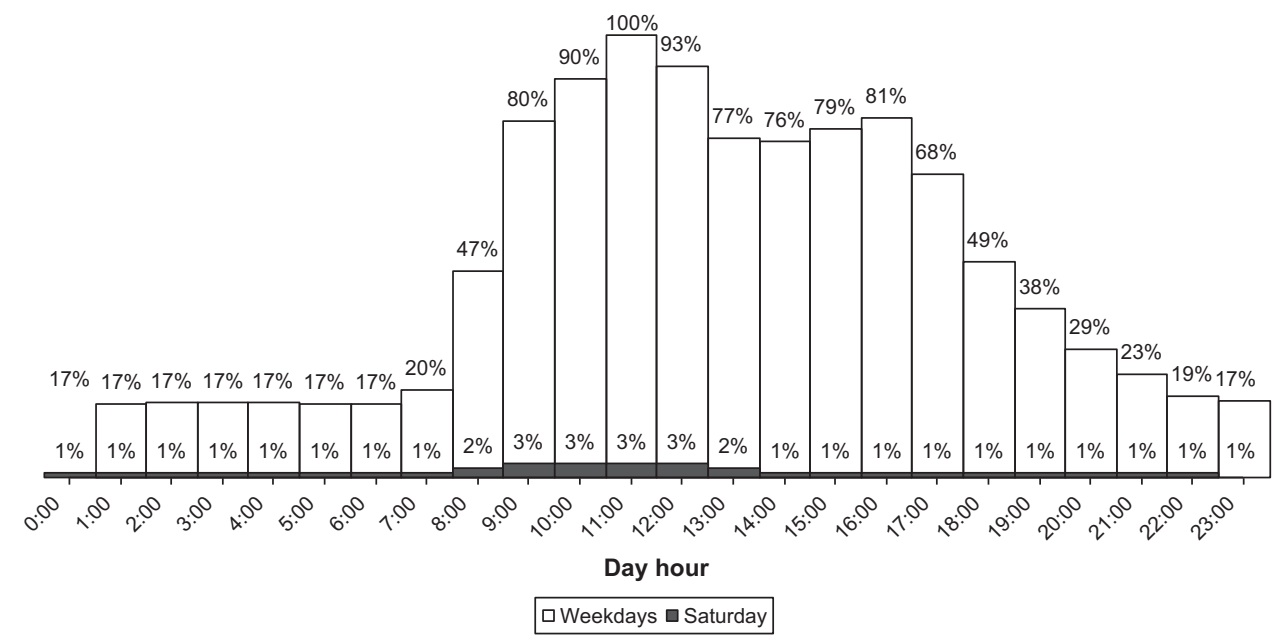

Fig. 4. Lighting and equipment diagrams for weekdays and Saturday.

- $15 \mathrm{~m}^{2}$ /occupant-three occupants (240 W-sensible heat, $120 \mathrm{~W}$-latent heat);

- $10 \mathrm{~W} / \mathrm{m}^{2}$ for lighting (490 W); and

- $5 \mathrm{~W} / \mathrm{m}^{2}$ for equipment $(245 \mathrm{~W})$.

These parameters are difficult to predict, so it must have adopted reference standards for use in buildings, such as those described in RSECE (2006).

Regarding the level of occupancy of a building, the release of sensible and latent heat inherent to each person must be taken into consideration, a value that varies according to the degree of activity.

\subsection{Control of the electrochromic glass}

The modulation of the electrochromic glass was achieved by the adaptation of a module designed for ESP-r and intended to simulate the use of shutters, entitled "Black Box Model" (Frontini et al. 2009).

The parameterization of the EC Glass in the "Black Box Model" consists in the creation of a file with the optical properties of the glass for a set of six possible states of coloration, including the clear state (State 1) and full-color (Condition 6). However, in reality, the control of the state of the EC glass can be done continuously. These six states were defined with the list of properties listed in Fig. 5.

As the solar factor $(g)$, the solar transmittance $\left(\tau_{\text {solar }}\right)$ and solar reflectivity $\left(\rho_{\text {solar }}\right)$ of the glasses are a function of the angle of solar incidence, to prepare the text file with the optical properties of each of the states for the entire solar spectrum, it was necessary to use the equations that permit to calculate the optical properties ( $\left.\tau_{\text {solar }}, g, \rho_{\text {solar }}\right)$ for each solar height and solar azimuth that will be used in the text file. The formulation used (see Eqs. (1)-(4)) is based on the equations from Rosenfeld (1996), Roos et al. (2000, 2001), Kuhn (2006), and Kuhn et al. (2011), validated by Platzer (2000), Rosenfeld et al. (2000), Karlsson and Roos (2000), Roos et al. (2000), and Karlsson et al. (2001). Thus, it was possible to calculate, based on the values presented in Table 2 , the values of $\tau_{\text {solar }}, g$ and $\rho_{\text {solar }}$, for the solar azimuth range of $\left[-90^{\circ}, 90^{\circ}\right]$ and solar height range of $\left[-90^{\circ}, 90^{\circ}\right]$, with increments of $5^{\circ}$.

$g_{\text {glass }}\left[\alpha_{\text {in }}\right]=g_{\text {glass }}\left[0^{\cdots}\right]\left(1-a_{\text {roos }}\left(\frac{\alpha_{\text {in }}}{90 *}\right)^{\alpha_{\text {roos }}}-b_{\text {roos }}\left(\frac{\alpha_{\text {in }}}{90 *}\right)^{\beta_{\text {roos }}}-c_{\text {roos }}\left(\frac{\alpha_{\text {in }}}{90 *}\right)^{\gamma_{\text {roos }}}\right)$ 


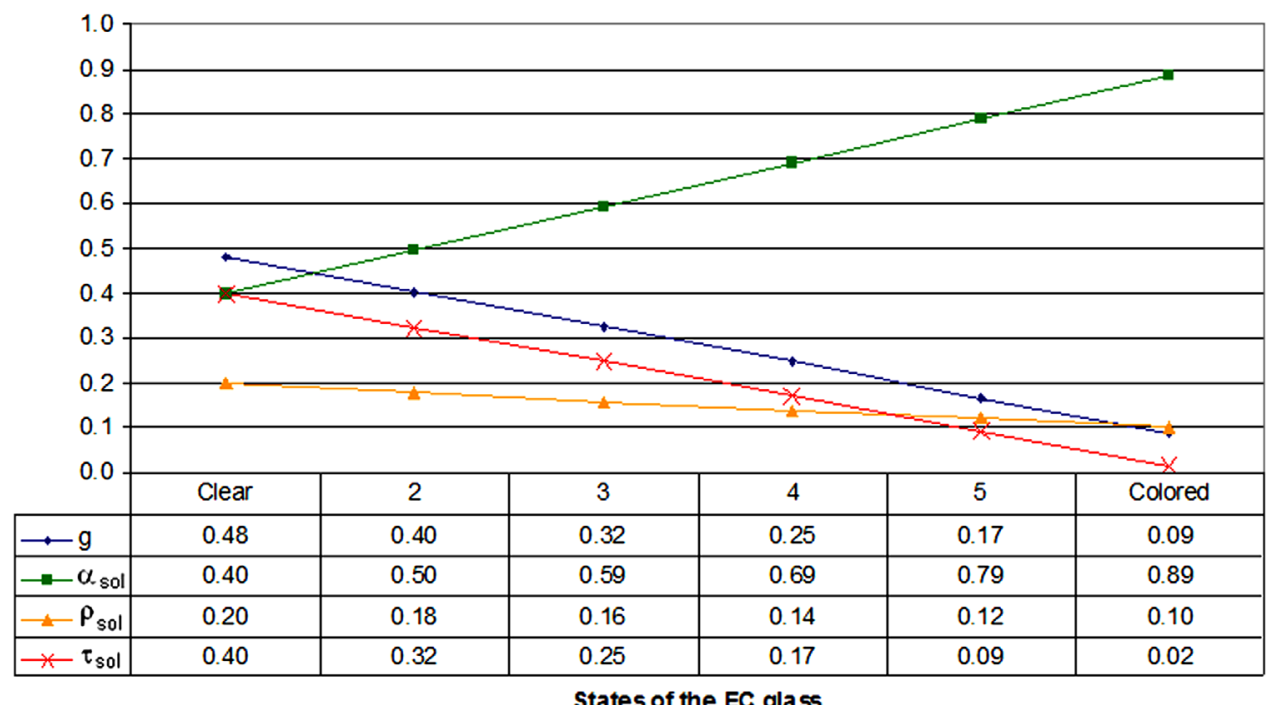

Fig. 5. Optical properties, for normal incidence, of the six states of the EC glass.

Table 2

Parameters used to calculate $\left(\tau_{\mathrm{sol}, \perp}, g_{\perp}, \rho_{\mathrm{sol}, \perp}\right)$.

\begin{tabular}{|c|c|c|}
\hline Parameters & Value & Notes \\
\hline$p_{\text {roos }}$ & 2.00 & Number of glass panes separated by an air layer \\
\hline$q_{\text {roos }}$ & 1.00 & Fixed parameter \\
\hline $\boldsymbol{b}_{\text {roos }}$ & 0.25 & Fixed parameter \\
\hline$c_{\text {roos }}$ & -7.25 & Fixed parameter \\
\hline$\alpha_{\text {roos }}$ & 5.90 & Fixed parameter \\
\hline$\beta_{\text {roos }}$ & 2.00 & Fixed parameter \\
\hline$\gamma_{\text {roos }}$ & 6.19 & Fixed parameter \\
\hline $\mathbf{g}\left(\alpha=\mathbf{0}^{\circ}\right)$ & 0.48 & Variable parameter \\
\hline$\tau_{\text {sol }}\left(\alpha=\mathbf{0}^{\circ}\right)$ & 0.40 & Variable parameter \\
\hline$\rho_{\text {sol }}\left(\alpha=0^{\circ}\right)$ & 0.20 & Variable parameter \\
\hline$\alpha_{\text {sol }}\left(\alpha_{\text {in }}=0^{\circ}\right)$ & 0.40 & Fixed parameter $\left(\alpha_{\text {in }}:\right.$ solar incidence angle $)$ \\
\hline$\phi$ & 0.00 & Orientation of the facade $\left(0^{\circ}=\right.$ south, positive west $)$ \\
\hline$\phi_{\mathbf{s}}$ & - & Variable parameter: solar azimuth angle $\left(0^{\circ}=\right.$ south, west positive $)$ \\
\hline$\phi_{\mathrm{f}}$ & - & Variable parameter: $\phi_{\mathrm{f}}=\phi_{\mathrm{s}}-\phi$ (façade azimuth angle, $0^{\circ}$ parallel to facade normal) \\
\hline$\alpha_{\mathrm{s}}$ & - & Variable parameter: solar altitude angle \\
\hline
\end{tabular}

$\tau_{\text {sol,glass }}\left[\alpha_{\text {in }}\right] \approx \tau_{\text {sol,glass }}\left[0^{\circ}\right]\left(1-a_{\text {roos }}\left(\frac{\alpha_{\text {in }}}{90^{\circ}}\right)^{\alpha_{\text {roos }}}-b_{\text {roos }}\left(\frac{\alpha_{\text {in }}}{90^{\circ}}\right)^{\beta_{\text {roos }}}-c_{\text {roos }}\left(\frac{\alpha_{\text {in }}}{90^{\circ}}\right)^{\gamma_{\text {roos }}}\right)$

$\rho_{\text {sol,glass }}\left(\alpha_{\text {in }}\right) \approx\left\{\begin{array}{c}1-\tau_{\text {sol,glass }}\left(\alpha_{\text {in }}\right)-\underbrace{\left[1-\rho_{\text {sol,glass }}\left(\alpha_{\text {in }}=0^{\circ}\right)-\tau_{\text {sol,glass }}\left(\alpha_{\text {in }}=0^{\circ}\right)\right]}_{\text {absortivity for normal incidence } \alpha\left(\alpha_{\text {in }}=0^{\circ}\right)} \text { if } \alpha_{\text {in }} \leq 75^{\circ} \\ 1-\tau_{\text {sol,glass }}\left(\alpha_{\text {in }}\right)-\alpha\left(\alpha_{\text {in }}=0^{\circ}\right) \frac{\alpha_{\text {in }}-90^{\circ}}{15^{\circ}} \text { if } \alpha_{\text {in }}>75^{\circ}\end{array}\right.$

$\tau_{\text {sol,glass }}\left[\alpha_{\text {in }}\right] \approx \tau_{\text {sol,glass }}\left[0^{\circ}\right]\left(1-a_{\text {roos }}\left(\frac{\alpha_{\text {in }}}{90^{\circ}}\right)^{\alpha_{\text {roos }}}-b_{\text {roos }}\left(\frac{\alpha_{\text {in }}}{90^{\circ}}\right)^{\beta_{\text {roos }}}-c_{\text {roos }}\left(\frac{\alpha_{\text {in }}}{90^{\circ}}\right)^{\gamma_{\text {roos }}}\right)$

In these equations the parameters $a_{\text {roos }}, b_{\text {roos }}, c_{\text {roos }}, \alpha_{\text {roos }}, \beta_{\text {roos }}$ and $\gamma_{\text {roos }}$ correspond to constants defined by:

$\alpha_{\text {roos }} \quad 5.2+0.7 \times q_{\text {roos }}$

$\beta_{\text {roos }}$

$\gamma_{\text {roos }}$

$a_{\text {roos }}$

$b_{\text {roos }}$

$c_{\text {roos }}$

$q_{\text {roos }}$

$p_{\text {roos }}$

$$
\begin{aligned}
& 5.2+0.7 \times q_{\text {roos }} \\
& 2 \\
& \left(5.26+0.06 \times p_{\text {roos }}\right)+\left(0.73+0.04 \times p_{\text {roos }}\right) \times q_{\text {roos }} \\
& 8 \\
& 0.25 / q_{\text {roos }} \\
& 1-a_{\text {roos }}-b_{\text {roos }} \\
& 1 \text { (for EC glasses) } \\
& 2 \text { (number of glass panes separated by an air layer) }
\end{aligned}
$$

As the determination of the sets of optical properties is a function of the orientation of the facade, it is necessary to create a file for each of the geographical orientations studied with EC (east, south and west), in a format recognized by the simulator (Frontini et al., 2009).

Each text file has the values of $\tau_{\text {solar }, \perp}, g_{\perp}$ and $\rho_{\text {solar, }, \text { for solar }}$ incidence range in each of the six discrete states defined for EC glass. During the simulation process, the state of the EC glass is determined according to the value of the control variable. Based on the instant height and solar azimuth, in each step of the simulation, the optical properties of the EC glass are obtained from the text file.

The current "Black Box Model" has five possible glazing control options (Frontini et al., 2009), namely by the air temperature zone, the outside air temperature, the incident radiation on an outside surface, the level of zone illuminance and the air temperature of another zone.

Following the criterion of Roos et al. (2005) an hourly time step for the dynamic simulations was adopted, which is considered adequate for typical the operation and control conditions of the EC windows. In fact, Kraft and Rottmann (2009) state that for $1 \mathrm{~m}^{2}$ the transition duration from clear to colored and back to clear is about $20 \mathrm{~min}$. According to the scarce data available in the literature it is foreseeable 
that the alteration of the EC glasses state does not occur with a high frequency. In addition, the time constant of older buildings which require rehabilitation is usually very high, and thus, from the viewpoint of the thermal response of the building or indoor thermal conditions it is not useful to consider frequent variations of the EC glass state (Roos et al., 2005).

\subsection{Simulations}

Table 3 lists the 24 simulations that were performed for each window orientation (east, south and west). The simulations code corresponds to a sequential numbering. The index "e" and " $w$ " refer to the glass on the east and west facades, respectively, and the number without index refers to the glass on the south façade. The description field complete the information about the simulation criteria, namely the considered setpoint $\left(20 / 25^{\circ} \mathrm{C}\right)$, the conditioning period (for example, $8-20 \mathrm{~h}$ ), the EC control parameter (indoor temperature, outdoor temperature, incident solar radiation) and the transition conditions for each of the states of the EC glass. If no information is presented the parameter is not considered in the parameterization of the simulation.

The simulation exercises were conducted with the perspective to evaluate both the passive behavior and the energy performance for space heating and cooling. In accordance with the Portuguese building regulation (RSECE, 2006) for the condition of space airconditioned, during the building occupation period an air temperature set point value of $20{ }^{\circ} \mathrm{C}$ was used for heating and of $25{ }^{\circ} \mathrm{C}$ for cooling. This criterion creates a dead band between $20 / 25^{\circ} \mathrm{C}$, wherein the indoor air temperature is not controlled. During the non-occupancy periods the air temperature in the zone is not controlled, thus varying consistently with the heat losses and gains of the thermal zone.

In Portugal and south European regions the south facade of buildings is the one that receives more solar radiation throughout the year. Contrary to this, the North facades only receive diffuse radiation during wintertime and during the cooling period they receive direct solar radiation during a short period at the early morning and late afternoon. Therefore, the North facades were not considered for the study with EC glasses, because their control certainly does not result in significant energy savings. The east and west facades although they receive low solar radiation during the heating season, by the fact that during the cooling season the sun presents an apparent path close to perpendicular of the east (during the morning) and west (during the afternoon) facades, the solar radiation incidence in this facades is intense and therefore these oriented spaces present overheating problems. Therefore, the east, south and west orientations were considered for the study.

In the situation of double glazing with improved physical properties it has the following characteristics $U=1.50 \mathrm{~W} /\left(\mathrm{m}^{2} \mathrm{~K}\right)$ and for an angle of incidence of $0^{\circ}, g_{\perp}=0.46 ; \rho_{\mathrm{sol}, \perp}=0.12 ; \tau_{\mathrm{sol}, \perp}=0.38 ; \alpha_{\mathrm{sol}, \perp}=$ 0.50 . We have two double glazings (PLANITHERM-outdoor/PLANILUX-interior) with $4 \mathrm{~mm}$ each and a box with $12 \mathrm{~mm}$ air filled with air (6\%) and argon. The properties of this glass were calculated using the program that calculates the optical properties of glasses known as "WINDOW 5.2a v5.2.17a". The results of the properties obtained with "WINDOW" were introduced in the ESP-r database so they can be used. The results of "WINDOW" are imported directly to the ESP-r without any additional treatment.

Some of the works based in simulation (for example, Karlsson (2001)) present results only for the cooling season, assuming that during the heating season the glass is always in the clear state, not contributing to the increased need for heating energy. Nevertheless, the study developed here was based on a seasonal and annual base, assuming the year divided into heating and cooling seasons.

The weather file from Coimbra was used for the simulations. Coimbra is a city in the center of Portugal mainland at latitude of $40.210^{\circ} \mathrm{N}$, longitude of $8.430^{\circ} \mathrm{W}$ and elevation above sea level of $140 \mathrm{~m}$. Table 4 presents monthly statistical meteorological data for Coimbra extracted from the weather file used for the building energy simulations.

\section{Results and discussion}

The single glass solution is the current status of the majority of service buildings constructed in the middle of the last century, corresponding to the principal building stock candidate to be subject to rehabilitation during the next decade in Portugal and in many

Table 3

Simulations identification and description.

\begin{tabular}{|c|c|}
\hline Simulation & Description \\
\hline $1 \mathrm{e} / 1 / 1 \mathrm{w}$ & Interior temperature of the test cell; $25 / 24 / 23 / 22 / 21 / 1\left({ }^{\circ} \mathrm{C}\right)$ \\
\hline $2 \mathrm{e} / 2 / 2 \mathrm{w}$ & Incident radiation on the test cell glass; $100 / 80 / 60 / 40 / 20 /-10\left(\mathrm{~W} / \mathrm{m}^{2}\right)$ \\
\hline $3 e / 3 / 3 w$ & $20 / 25^{\circ} \mathrm{C} ; 8-20 \mathrm{~h}$; interior temperature of the test cell; $25 / 24 / 23 / 22 / 21 / 1\left({ }^{\circ} \mathrm{C}\right)$ \\
\hline $4 \mathrm{e} / 4 / 4 \mathrm{w}$ & $20 / 25^{\circ} \mathrm{C} ; 8-20 \mathrm{~h}$; incident radiation on the test cell glass; $100 / 80 / 60 / 40 / 20 /-10\left(\mathrm{~W} / \mathrm{m}^{2}\right)$ \\
\hline $5 e / 5 / 5 w$ & The same as simulation 1, the EC glass always in the clear state \\
\hline $6 e / 6 / 6 w$ & The same as simulation 1 , the EC glass always in the colored state \\
\hline $7 e / 7 / 7 w$ & The same as simulation 3 , the EC glass always in the clear state \\
\hline $8 \mathrm{e} / 8 / 8 \mathrm{w}$ & The same as simulation 4 , the EC glass always in the clear state \\
\hline $9 e / 9 / 9 w$ & The same as simulation 4 , the EC glass always in the colored state \\
\hline $10 \mathrm{e} / 10 / 10 \mathrm{w}$ & The same as simulation $4,250 / 200 / 150 / 100 / 20 /-10\left(\mathrm{~W} / \mathrm{m}^{2}\right)$ \\
\hline $11 \mathrm{e} / 11 / 11 \mathrm{w}$ & $20 / 25^{\circ} \mathrm{C} ; 8-20 \mathrm{~h} ;$ outside temperature; $27 / 26 / 25 / 24 / 23 / 1\left({ }^{\circ} \mathrm{C}\right)$ \\
\hline $12 \mathrm{e} / 12 / 12 \mathrm{w}$ & The same as simulation 1 , with glass on the entire facade (east/south/west) \\
\hline $13 e / 13 / 13 w$ & The same as simulation 3, with glass on the entire facade (east/south/west) \\
\hline $14 \mathrm{e} / 14 / 14 \mathrm{w}$ & The same as simulation 4 , with glass on the entire facade (east/south/west) \\
\hline $15 \mathrm{e} / 15 / 15 \mathrm{w}$ & The same as simulation 3 , the EC glass always in the colored state \\
\hline $16 e / 16 / 16 w$ & $20 / 25{ }^{\circ} \mathrm{C} ; 8-20 \mathrm{~h}$; incident radiation on the test cell glass; $250 / 200 / 150 / 100 / 20 /-10\left(\mathrm{~W} / \mathrm{m}^{2}\right)$ \\
\hline $17 \mathrm{e} / 17 / 17 \mathrm{w}$ & The same as simulation 16 , with glass on the entire facade (east/south/west) \\
\hline 18 & The same as simulation 2, with infiltrations air rate of $0.3 \mathrm{~h}^{-1}$ \\
\hline 19 & The same as simulation 4 , with infiltrations air rate of $0.3 \mathrm{~h}^{-1}$ \\
\hline $21 \mathrm{e} / 21 / 21 \mathrm{w}$ & The same as simulation 3 , the double glazing has improved physical properties \\
\hline $22 \mathrm{e} / 22 / 22 \mathrm{w}$ & The same as simulation 4 , the double glazing has improved physical properties \\
\hline 23 & The same as simulation 21 , the EC glass is always in the clear state \\
\hline 24 & The same as simulation 22 , the EC glass is always in the clear state \\
\hline 25 & The same as simulation 1 , the double glazing has improved properties \\
\hline
\end{tabular}


Table 4

Monthly statistical meteorological data for Coimbra.

\begin{tabular}{|c|c|c|c|c|c|c|c|c|c|c|c|c|}
\hline & January & February & March & April & May & June & July & August & September & October & November & December \\
\hline $\begin{array}{l}\text { Monthly mean dry bulb } \\
\text { temperature }(\mathbf{C})\end{array}$ & 9.6 & 11.0 & 12.7 & 13.1 & 15.6 & 19.0 & 20.8 & 21.1 & 20.6 & 16.9 & 12.2 & 11.2 \\
\hline $\begin{array}{l}\text { Daily monthly mean dry bulb } \\
\text { temperature range }\left({ }^{\circ} \mathrm{C}\right)\end{array}$ & 7.1 & 7.4 & 9.4 & 9.3 & 9.6 & 10.4 & 11.6 & 11.9 & 11.1 & 8.6 & 6.9 & 6.0 \\
\hline $\begin{array}{l}\text { Heating degree days, base } 18.3^{\circ} \mathrm{C} \\
\quad\left({ }^{\circ} \mathrm{C} / \text { day }\right)\end{array}$ & 259 & 206 & 162 & 136 & 77 & 18 & 2 & 2 & 11 & 63 & 146 & 216 \\
\hline $\begin{array}{l}\text { Daily monthly mean horizontal } \\
\text { global solar radiation }\left(\mathrm{Wh} / \mathbf{m}^{2}\right)\end{array}$ & 2093 & 2606 & 4084 & 5330 & 5802 & 6687 & 6819 & 6273 & 4787 & 3328 & 2043 & 1679 \\
\hline $\begin{array}{l}\text { Daily monthly mean horizontal } \\
\text { diffuse solar radiation }\left(\mathrm{Wh} / \mathrm{m}^{2}\right)\end{array}$ & 902 & 1474 & 1936 & 2298 & 2833 & 2866 & 2356 & 2120 & 1981 & 1482 & 1217 & 959 \\
\hline
\end{tabular}

Mediterranean cities. Therefore, the single glass was considered the reference solution for the results presentation and discussion.

The analysis of energy performance is based on the differences to the reference case (single glass) of the energy needs for heating, cooling and annual (heating+cooling). It was determined that the positive variations correspond to an increase in the energy needs and a negative variation corresponds to energy reductions.

The results for the heating and cooling needs considering glazing areas of $5.4 \mathrm{~m}^{2}$ and $25.84 \mathrm{~m}^{2}$ (simulations $12 \mathrm{e} / 12 / 12 \mathrm{w}, 13 \mathrm{e} / 13 / 13 \mathrm{w}$, $14 \mathrm{e} / 14 / 14 \mathrm{w}$ and $17 \mathrm{e} / 17 / 17 \mathrm{w}$ ) are presented in Tables 5 and 6 . In Table 5 it is considered that the useful floor area is $49 \mathrm{~m}^{2}$. The glazing area of $5.4 \mathrm{~m}^{2}$ corresponds to a WWR (Window to Wall Ratio) of $19.3 \%$ and a WFR (Window to Floor Ratio) of $11 \%$. The glazing area of $25.84 \mathrm{~m}^{2}$ corresponds to a WWR of $92.3 \%$ and a WFR of $52.7 \%$.

The results of Table 5 show that, regardless of geographic orientation of the glazed area, space heating needs are higher than the energy requirements for cooling. Moreover, the higher overall energy needs are obtained when the glazing is located on the west facade and the lower result observed for the south facade. The increase of the south glazing area results in a decrease of the specific energy needs for heating and an increase of energy needs for cooling. For east and west facades both heating and cooling needs increase with the increasing of glazing area.

The problem related with the control of solar heat gains in the east and west facades, particularly to avoid excessive direct gains during the cooling season, is underlined by the higher cooling needs of these when compared with the south facade.

With $25.84 \mathrm{~m}^{2}$ glazed area at south the annual energy needs for heating with single glass are reduced and the energy needs for cooling increases. The results in terms of energy needs are also reflected in the number of hours needed for heating or cooling. For the case of west glazing facade both the energy requirements and the number of hours for heating and cooling increase.

For the east orientation, the energy requirements for heating and cooling increase with the increasing of glass area. One fact to be noted to this particular orientation is the decrease of the number of hours for heating when the glass area increases. Although this decrease can be considered marginal it may be explained by the higher solar heat gains. However, if the glass area will be larger, higher thermal losses will occur, requiring higher thermal power (and energy) to achieve comfort conditions at the beginning of the building occupancy.

As noted by the analysis of the above results, the test cell energy requirements for cooling and heating with the window south-facing are lower than when it is on the east or west facades, with the worst results observed for the west facade. These results confirm and quantify the more difficulty to control the direct solar gains in these orientations.

Table 7 presents the results obtained when considering a lower air infiltration rate of $0.3 \mathrm{~h}^{-1}$, tested for the south facade and for a glazing area of $5.4 \mathrm{~m}^{2}$.
Table 5

Energy needs for the base situation with single glass $\left(\mathrm{kWh} / \mathrm{m}^{2} \mathrm{yr}\right)$.

\begin{tabular}{|c|c|c|c|c|c|c|}
\hline \multirow{2}{*}{$\begin{array}{l}\text { Area } \rightarrow \\
\text { Orientation } \rightarrow \\
\text { Energy for } \downarrow\end{array}$} & \multicolumn{3}{|c|}{$5.40 \mathrm{~m}^{2}$} & \multicolumn{3}{|c|}{$25.84 \mathrm{~m}^{2}$} \\
\hline & East & South & West & East & South & West \\
\hline Heating & 43.59 & 39.02 & 44.66 & 48.37 & 34.24 & 53.06 \\
\hline Cooling & 22.85 & 22.16 & 24.50 & 30.21 & 29.33 & 37.63 \\
\hline Annual & 66.45 & 61.18 & 69.17 & 78.58 & 63.58 & 90.68 \\
\hline
\end{tabular}

Table 6

Single glass results $(\mathrm{h} / \mathrm{yr})$

\begin{tabular}{|c|c|c|c|c|c|c|}
\hline \multirow{2}{*}{$\begin{array}{l}\text { Window orientation } \\
\text { Window area }\left(\mathrm{m}^{2}\right)\end{array}$} & \multicolumn{2}{|l|}{ East } & \multicolumn{2}{|l|}{ South } & \multicolumn{2}{|l|}{ West } \\
\hline & Heating & Cooling & Heating & Cooling & Heating & Cooling \\
\hline 5.4 & 2120 & 1469 & 2095 & 1452 & 2144 & 1477 \\
\hline 25.84 & 2072 & 1511 & 1837 & 1572 & 2168 & 1551 \\
\hline
\end{tabular}

Table 7

Results of simulation 19 for the base situation with single glass $\left(5.4 \mathrm{~m}^{2}\right)$.

\begin{tabular}{ll}
\hline Heating $-\mathrm{kWh} / \mathrm{m}^{2}$.year (hours/year) & Cooling $-\mathrm{kWh} / \mathrm{m}^{2}$. year (hours/year) \\
\hline 31.61 & 24.89 \\
$(1904)$ & $(1583)$ \\
\hline
\end{tabular}

\subsection{East facing glazing}

The results of energy needs for the double (DGU) and EC glass, relatively to the reference single glass (SG) solution, are presented in Figs. 6 and 7 for the east facade.

From the presented results it is possible to conclude:

(1) The DGU and EC glass always results in improvements of the energy needs, with better results for the EC glazing. For the heating season the results with DGU glass is always better than the solution considering EC glass, presenting both solutions better energy consumptions results than the reference single glass. For the cooling season the EC glass solution is always better than the other two glass technologies. DGU glazing always has lower performance results for the cooling season, except when the solar factor of the double glazing (improved double glass) is similar to the real EC glass.

(2) Simulation results 21e and 22e in Fig. 6 show that DGU with a solar factor similar to the EC SAGETM glass in the transparent (clear) state performs worse than EC. 


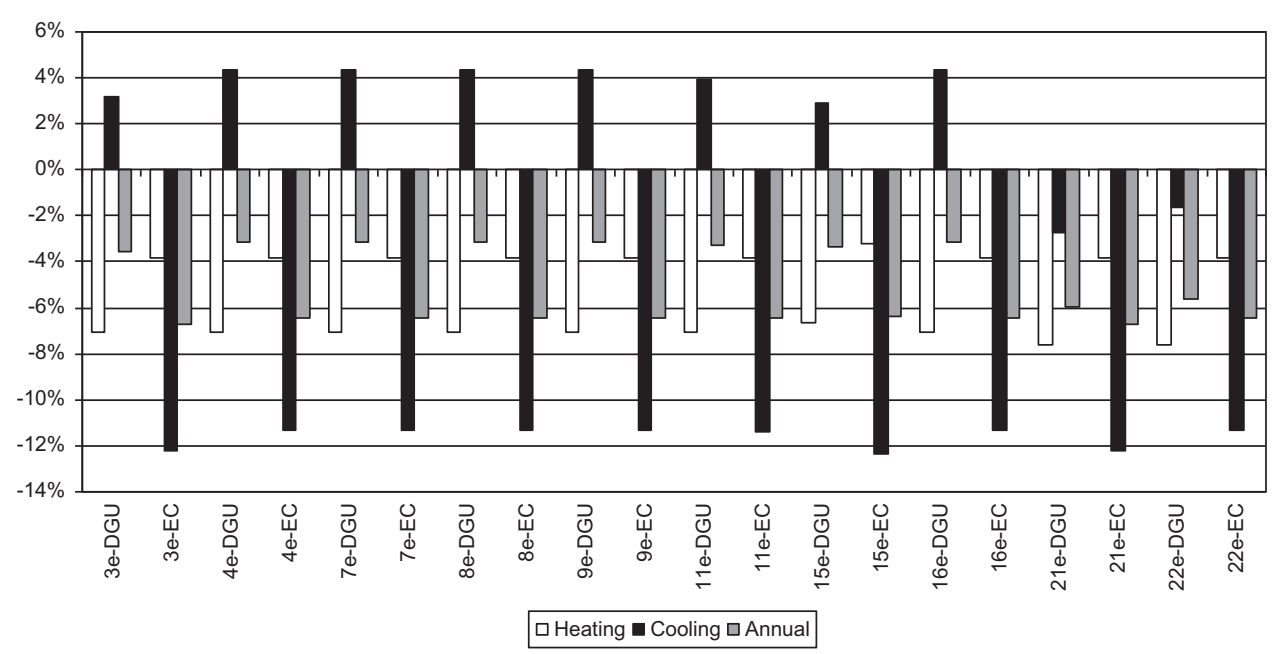

Fig. 6. Differences of the energy needs for heating, cooling and annual by the use of DGU and EC glass, $5.4 \mathrm{~m}^{2}$ glass area in east facade (SG as reference solution).

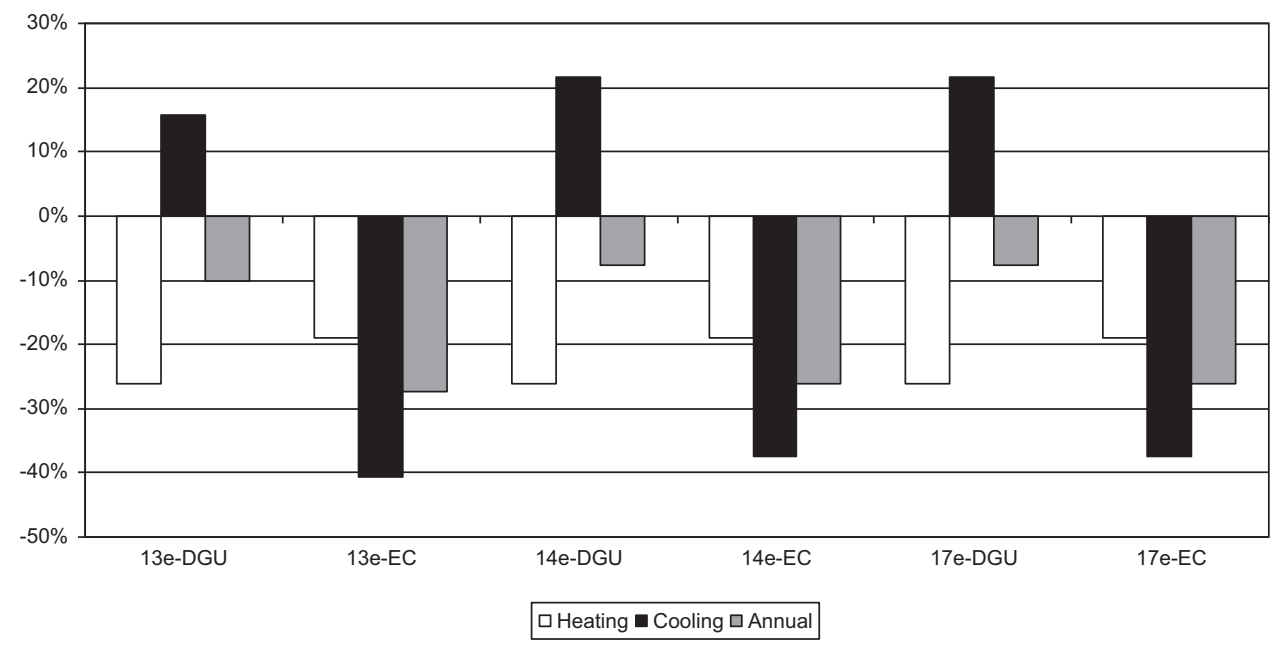

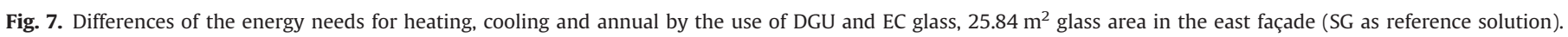

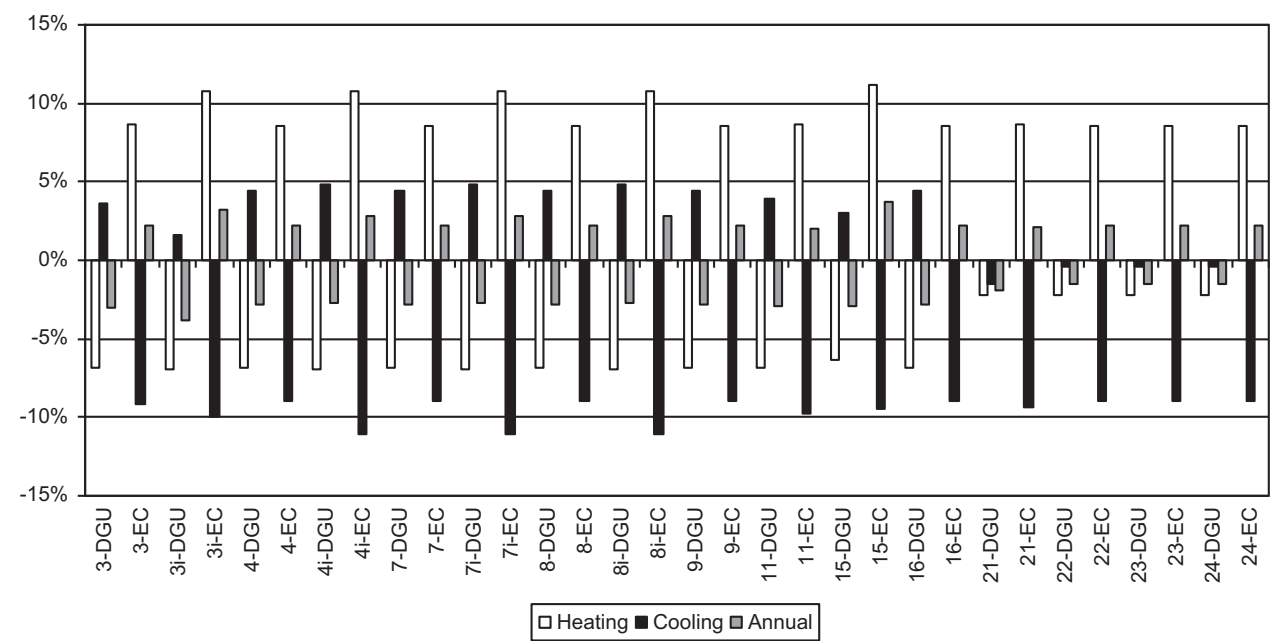

Fig. 8. Differences of the energy needs for heating, cooling and annual by the use of DGU and EC glass, $5.4 \mathrm{~m}^{2}$ glass area in south façade (SG as reference solution).

\subsection{South facing glazing}

Figs. 8 and 9 and Table 8 show the comparative results of the simulations, based on the situation described in Tables 5 and 7 , when the glass is placed on the south facade. By analyzing these results one may conclude:

(1) For the glass area of $5.4 \mathrm{~m}^{2}$, regardless of the electrochromic glass control, the annual results of overall electrochromic glass 


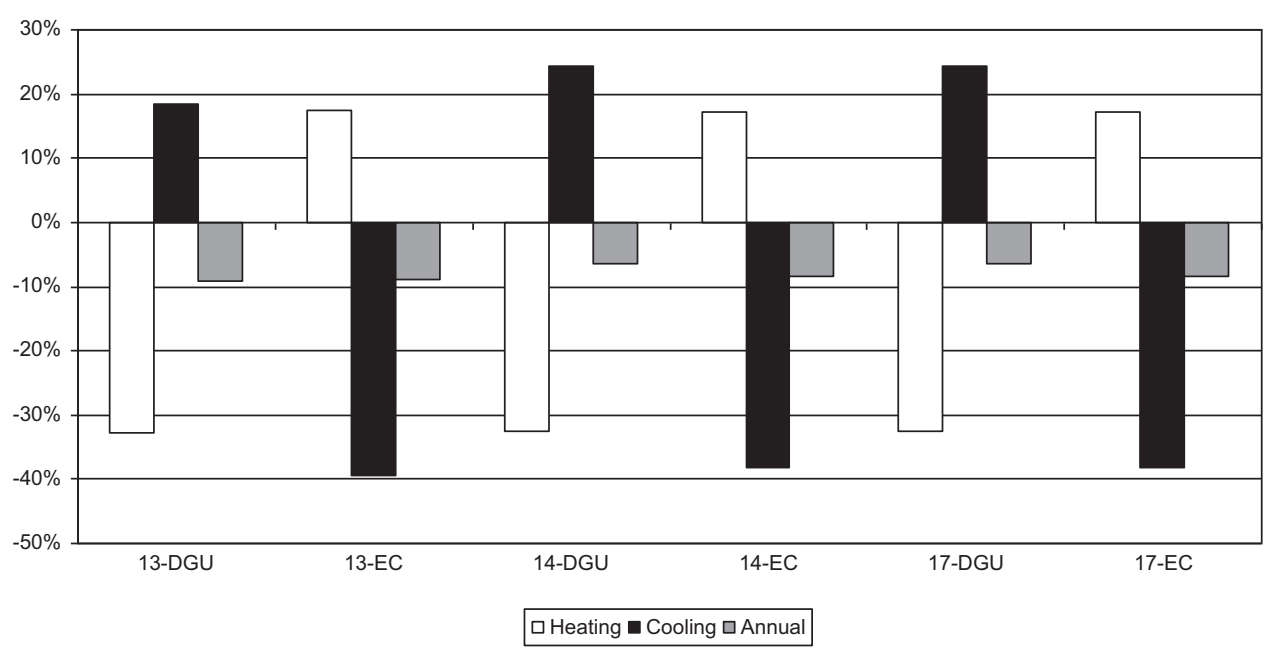

Fig. 9. Differences of the energy needs for heating, cooling and annual by the use of DGU and EC glass, $25.84 \mathrm{~m}^{2}$ glass area in south façade (SG as reference solution).

Table 8

Differences in the energy needs of simulation $19(\%)$.

\begin{tabular}{lccc}
\hline & Heating & Cooling & Annual \\
\hline Simulation 19 & & & \\
Double glass & -8 & 5 & -2 \\
EC double glass & 10 & -7 & 2 \\
\hline
\end{tabular}

always has lower performance than for the single or double conventional glass. However, the results with double glass are better than with single glass. Considering only the annual energy need for heating, double glazing has a better performance and EC glazing a lower performance. Considering only the cooling needs, the electrochromic glazing presents energy improvements when compared with the single and double current glass.

(2) For window area of $25.84 \mathrm{~m}^{2}$, the annual results (heating+cooling) of overall electrochromic windows are always better than for the single glass. When compared to the double glazing the results are dependent of the control type (see Fig. 8). Focusing on the annual heating needs, double glazing shows a significant improvement as regards to the base case while electrochromic glazing has slightly lower performance. Considering the cooling needs electrochromic glazing shows a significant improvement as regards to the base case while double glazing has slightly lower performance.

(3) If the air infiltration rates decrease the overall results are similar to those referred in comment (1) above. The annual energy needs for heating will reduce with double glass $(-7 \%)$ and increase with the solution of EC glass $(+13 \%)$. However, considering only the cooling needs the EC glass solution presents better results $(-8 \%)$ than the double glass $(+4 \%)$. By reducing the rate of infiltration of outside air to $0.3 \mathrm{~h}^{-1}$, the conclusions remain the same in relation to the initial situation $\left(0.6 \mathrm{~h}^{-1}\right)$. As such, it can be said that the high uncertainty that exists regarding the rate of air infiltration in buildings does not have effect on the general conclusions of the energy savings achieved by the use of EC glass in the test cell.

(4) If the solar factor of the double glazing would be equal to the solar factor of EC glazing in clear state, the double glazing improves the overall energy performance over single glazing and the EC glass solution is less efficient than the single and double glazing. The double glass has positive energy performance influence in both seasons, while the use of EC glass presents the reduction of energy for cooling, however with an increase of the energy for heating.

\subsection{West facing glazing}

Figs. 10 and 11 present the results of comparison with the base solution (Table 5), considering the glazing on the west facade. By analyzing these results one may conclude:

(1) When the window is located in the west facade the EC glass always contributes to improve the room energy performance and is more effective than the current double glazing. Also, EC glass was shown to be more useful in the west facade than in the east facade (compare with Figs. 6 and 7). When considering only the east and west facades, for the configuration with larger window area the savings on annual energy needs (heating plus cooling) are more than three times higher ( $\approx 100 \mathrm{kWh} / \mathrm{yr} \rightarrow \approx 350 \mathrm{kWh} / \mathrm{yr}$ ), when considering the replacement of single glass with double glass, and about five times higher $\quad(\approx 200 / 300 \mathrm{kWh} / \mathrm{yr} \rightarrow \approx 1000 / 1500 \mathrm{kWh} / \mathrm{yr}) \quad$ when admitting the application of EC glass.

(2) The EC glass always has higher influence in the energy performance improvement compared to the option of double glazing. It is also observed that the positive energy performance influence is higher in the west orientation than in the east orientation.

(3) Both current DGU and EC glazing show energy advantages for the heating season when compared to the single glazing solution. When the lower glass area is considered the energy savings are higher for the current DGU glass solution (see Fig. 10). For the larger glass area the energy savings for heating with EC glass are higher than with the DGU glass solution. During the cooling season the EC glass reduces the energy needs for cooling and the double glass increases the need of energy for cooling with the exception of the use of double glazing with improved physical properties (21w and $22 \mathrm{w})$.

The results show that to a larger glazing area in east and west facades (about five times), the reductions in annual energy requirements (heating plus cooling) is about $66 \%$ when considering double glazing, and about $80 \%$ when it is used EC glass.

A comparative analysis of results obtained with three different ways of controlling the EC glass (indoor air temperature of the test cell, outdoor air ambient temperature and incident solar radiation on the EC glass) concluded that the control by the outside temperature and the inside temperature of the cell test, have less effective results (simulations $3 \mathrm{e} / 3 / 3 \mathrm{w}$ and $11 \mathrm{e} / 11 / 11 \mathrm{w}$ ) than when considering the incident solar radiation (simulations $4 \mathrm{e} / 4 / 4 \mathrm{w}$ ). 


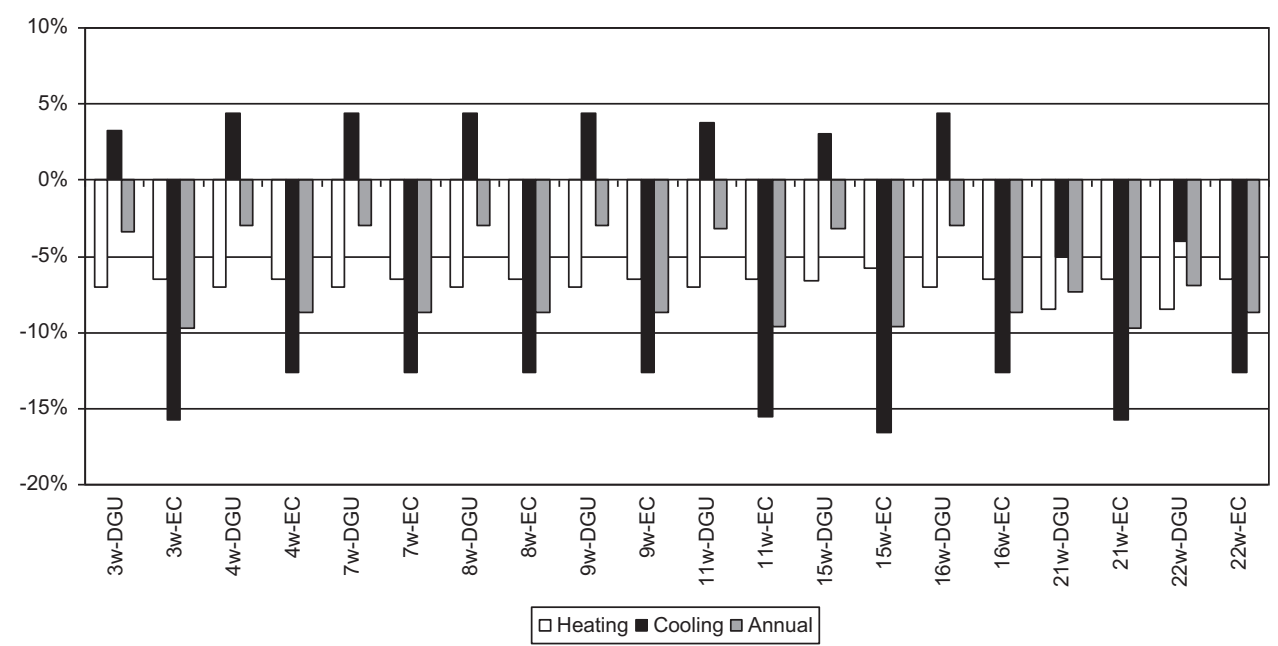

Fig. 10. Differences of the energy needs for heating, cooling and annual by the use of DGU and EC glass, $5.4 \mathrm{~m}^{2}$ glass area in west façade (SG as reference solution).

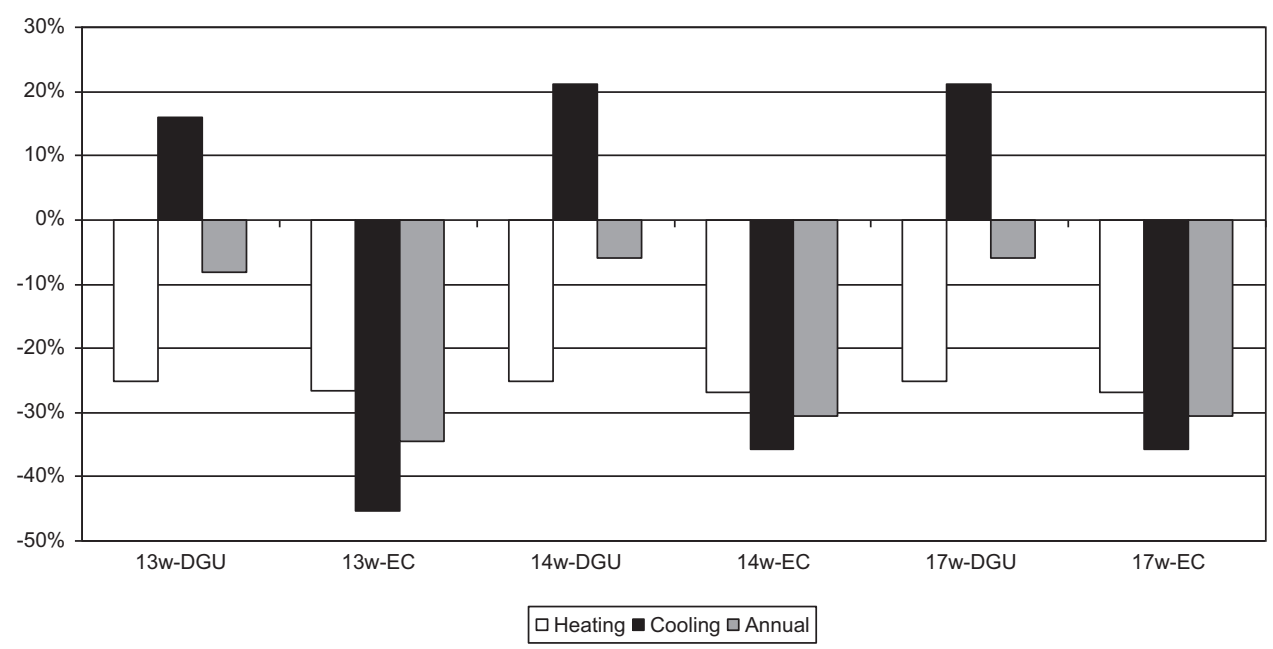

Fig. 11. Differences of the energy needs for heating, cooling and annual by the use of DGU and EC glass, $25.84 \mathrm{~m}^{2}$ glass area in west façade (SG as reference solution).

For all orientations, in the heating season EC glasses should be almost always in the transparent state, and effective control being achieved for the intermediate and cooling seasons.

Table 9 shows the obtained peak load for heating and cooling for simulations $3 \mathrm{e} / 3 / 3 \mathrm{w}$ and $4 \mathrm{e} / 4 / 4 \mathrm{w}$. Independently of the glazing type the peak load for heating occurs at beginning of January, 11th. For all situations the peak load for cooling occurs during August, 12th at different hours, as can be seen in Fig. 12. The results show slightly lower values of the maximum heating and cooling load when the EC glass is considered.

Fig. 12 shows that regardless of the orientation of the facade where the glass is admitted the values of the maximum cooling power for the situation of single and double-glazing are close (differences less than 1\%).

Evaluating the results with the use of EC glass, it may also be concluded that the values of maximum cooling are almost independent of the control variable. The differences are between $2 \%$ and $5 \%$. The lowest value of the maximum cooling load corresponds to control the EC glass according to the inside temperature of the test cells.

When comparing the use of EC glass with single glass, the reduction on the maximum cooling power is $15 \%$ for the east facade, $9 \%$ for the south facade and $16 \%$ for the west facade.

Regarding the use of single glass, the maximum cooling load with the use of double glazing in the east orientation is anticipated. This phenomenon is due to the lower energy losses by the double glazing due to the lower $U$-value $\left(2.80 \mathrm{~W} / \mathrm{m}^{2} \mathrm{~K}\right.$ for double glass and $5.79 \mathrm{~W} / \mathrm{m}^{2} \mathrm{~K}$ for the single glass). The action(s) of the EC glass in the reduction of the space solar gains, results in a delay in the maximum cooling demand. Regarding the use of single or double glass, in the west facade the occurrence of maximum cooling load is advanced when using EC glass. In the south facade the time of maximum cooling load occurrence is independent of the glass type.

The maximum cooling demand for double glass solution in the east facade occurs within one hour earlier than the situation of single glass, a phenomenon related with the difference of glass $U$ values. The higher $U$-value of the single glass promotes higher energy losses from the interior space to the exterior than with the double glazing during the morning hours, when the outdoor air temperature is below the reference space temperature of $25^{\circ} \mathrm{C}$ (see Fig. 13). The higher losses by single glass delay and reduce the heat accumulation within the building thermal mass, also contributing to the delay and reduction of the space thermal load.

\subsection{Simplified economic analysis}

The nonexistence of large-scale EC production and thus a competitive market result in actual high cost of the EC glass technology. For example, the cost of commercially available products from SAGE ${ }^{\mathrm{TM}}$ and 
Gesimat is around $1000 € / \mathrm{m}^{2}$. However, important cost depreciation could happen with the maturation of the technology and the production process, and market demand for use in new and rehabilitated buildings. In this context and for the purpose of conducting an economic study a simplified analysis is developed with the perspective to determine the costs that will make the technology viable.

Considering that the EC glass has "memory effect", i.e., it is only necessary to provide energy to stimulate a transition from one sate to another and not to maintain the state, and that the energy required to this stimulus is negligible, the supply electrical energy is ignored in this analysis.

Investment decisions on technology replacements depend strongly on the discount rate assumed by each decision maker,

Table 9

Maximum heating and cooling power for simulations 3e/3/3w e 4e/4/4w.

\begin{tabular}{|c|c|c|c|c|}
\hline & \multicolumn{2}{|c|}{ Heating } & \multicolumn{2}{|c|}{ Cooling } \\
\hline & $(\mathrm{kW})$ & 11th January & $(\mathrm{kW})$ & 12th August \\
\hline \multicolumn{5}{|l|}{ East } \\
\hline \multicolumn{5}{|l|}{$3 e$} \\
\hline Single & 3.12 & $10 \mathrm{~h} 30 \mathrm{~min}$ & 2.54 & $11 \mathrm{~h} 30 \mathrm{~min}$ \\
\hline Double & 3.01 & $10 \mathrm{~h} 30 \mathrm{~min}$ & 2.53 & $10 \mathrm{~h} 30 \mathrm{~min}$ \\
\hline EC & 2.97 & $10 \mathrm{~h} 30 \mathrm{~min}$ & 2.16 & $12 \mathrm{~h} 30 \mathrm{~min}$ \\
\hline \multicolumn{5}{|c|}{$20=5$} \\
\hline Single & 3.12 & 10 h30 min & 2.58 & $11 \mathrm{~h} 30 \mathrm{~min}$ \\
\hline Double & 3.00 & $10 \mathrm{~h} 30 \mathrm{~min}$ & 2.59 & $10 \mathrm{~h} 30 \mathrm{~min}$ \\
\hline EC & 2.97 & 10 h30 min & 2.22 & $12 \mathrm{~h} 30 \mathrm{~min}$ \\
\hline \multicolumn{5}{|l|}{ South } \\
\hline \multicolumn{5}{|l|}{3} \\
\hline Single & 3.10 & $10 \mathrm{~h} 30 \mathrm{~min}$ & 2.47 & $13 \mathrm{~h} 30 \mathrm{~min}$ \\
\hline Double & 3.00 & $10 \mathrm{~h} 30 \mathrm{~min}$ & 2.44 & $13 \mathrm{~h} 30 \mathrm{~min}$ \\
\hline EC & 3.02 & $10 \mathrm{~h} 30 \mathrm{~min}$ & 2.24 & $13 \mathrm{~h} 30 \mathrm{~min}$ \\
\hline \multicolumn{5}{|c|}{ 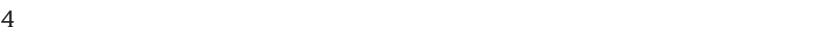 } \\
\hline Single & 3.10 & 10 h30 min & 2.50 & $13 \mathrm{~h} 30 \mathrm{~min}$ \\
\hline Double & 3.00 & $10 \mathrm{~h} 30 \mathrm{~min}$ & 2.48 & $13 \mathrm{~h} 30 \mathrm{~min}$ \\
\hline $\mathrm{EC}$ & 3.02 & $10 \mathrm{~h} 30 \mathrm{~min}$ & 2.28 & $10 \mathrm{~h} 30 \mathrm{~min}$ \\
\hline \multicolumn{5}{|l|}{ West } \\
\hline \multicolumn{5}{|l|}{$3 w$} \\
\hline Single & 3.13 & $10 \mathrm{~h} 30 \mathrm{~min}$ & 2.62 & $16 \mathrm{~h} 30 \mathrm{~min}$ \\
\hline Double & 3.01 & $10 \mathrm{~h} 30 \mathrm{~min}$ & 2.59 & $16 \mathrm{~h} 30 \mathrm{~min}$ \\
\hline EC & 2.96 & $10 \mathrm{~h} 30 \mathrm{~min}$ & 2.18 & $15 \mathrm{~h} 30 \mathrm{~min}$ \\
\hline Single & 3.13 & $10 \mathrm{~h} 30 \mathrm{~min}$ & 2.66 & $16 \mathrm{~h} 30 \mathrm{~min}$ \\
\hline Double & 3.01 & $10 \mathrm{~h} 30 \mathrm{~min}$ & 2.63 & $16 \mathrm{~h} 30 \mathrm{~min}$ \\
\hline EC & 2.96 & 10 h30 min & 2.28 & 15 h30 min \\
\hline
\end{tabular}

which translates directly into the time span for full investment recovery. In order to facilitate the assessment of the EC option, admissible extra cost values of the EC option as compared to DGU were calculated for various time periods. Considering only the building energy operational cost and assuming an unitary coefficient of performance (COP) for heating and an energy efficiency ratio (ERR) of 2 for cooling, Table 10 presents the exercise for EC glass in east façade and Table 11 for EC glass in the west façade, considering in both cases a window area of $5.4 \mathrm{~m}^{2}$.

Additional to this operational cost analysis, other savings components could be discussed in a more detailed analysis. Namely, the reduction of the installed HVAC system capacity, there is no need for additional blinds, increase thermal and visual comfort (no glare), increased productivity, possible energy savings in the artificial lighting system, decrease the installed electrical power of the building and maximum power demand to the electrical grid (Sanders and Podbelski, 2009, 2010; Sanders, 2010).

The cooling energy savings will be higher in buildings in warmer climates than the Portuguese case. It is likely that the achieved energy savings can contribute to mitigate the high cost of current commercially available EC glass $\left(1000 € / \mathrm{m}^{2}\right)$, and thus contributing to increased the use on a large scale, and consequently to reduce the production cost.

Several authors reported results of annual energy savings above $100 \mathrm{kWh} / \mathrm{m}^{2}$ glass.year by the use of EC glass. For example, admitting a solar radiation incidence on a south oriented window of $1000 \mathrm{kWh} / \mathrm{m}^{2}$ yr, Granqvist (2001), Azens and Granqvist (2003), Azens et al. (2005), Niklasson and Granqvist (2007), Granqvist (2007) and Granqvist (2008) reported annual savings of $170 \mathrm{kWh} /$ $\mathrm{m}^{2}$ glass.year. Syrrakou et al. (2005) refer typical values for energy savings by the use of EC glass in the order of $120-340 \mathrm{kWh} /$ $\mathrm{m}^{2}$ glass.year. Karlsson (2001) analyzed three different climates (Stockholm, Sweden, Denver and Miami, USA) and obtained annual energy savings between 0 and $150 \mathrm{kWh} / \mathrm{m}^{2}$ glass.year, and indicates an average value for annual energy savings of $100 \mathrm{kWh} / \mathrm{m}^{2}$ glass. year. From the present study the operational energy savings are in the range 20-37 kWh/m² glass.year (see Tables 9 and 10), showing less favorable results for the use of EC windows.

Although several studies (Karlsson, 2001; Lee et al., 2004; Jonsson and Roos, 2010a, 2010b) show the feasibility of using EC windows also on the south facade, the present results show that the use of EC glass is only interesting on the east and west facades. A justification for the results differences between this study and the findings of the major studies in the literature is related to the physical characteristics of the EC glasses considered. While in the present work it was adopted the physical characteristics of a

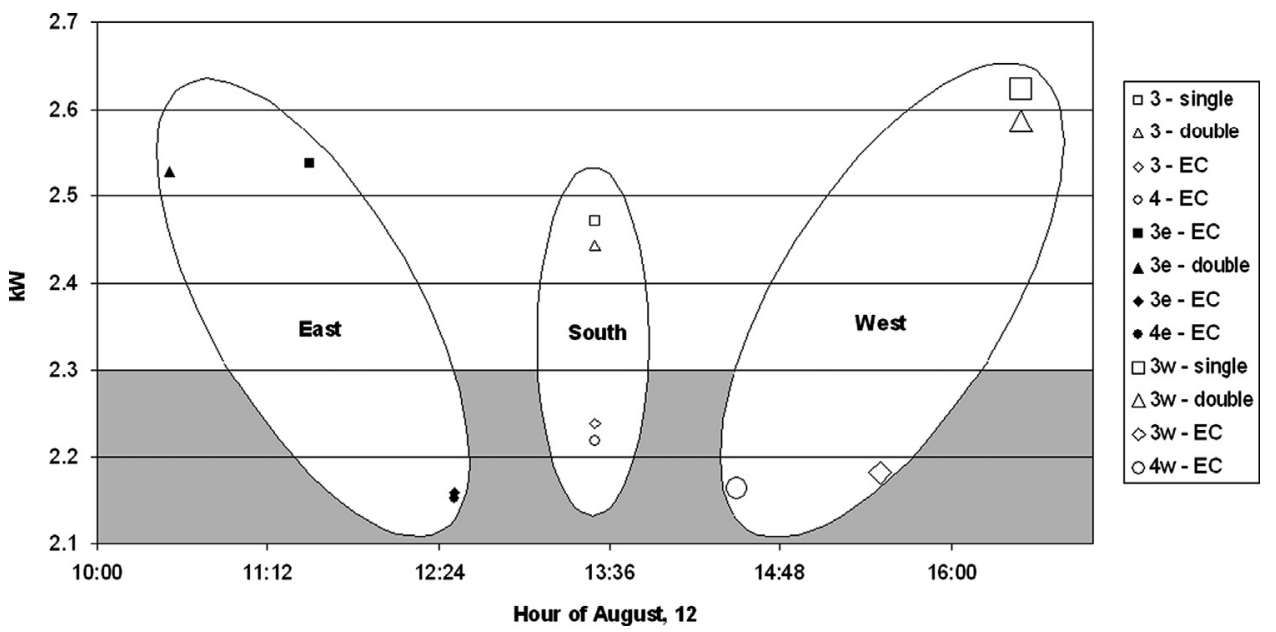

Fig. 12. Maximum cooling power for simulations 3e, 4e, 3, 4, 3w e 4 w. 


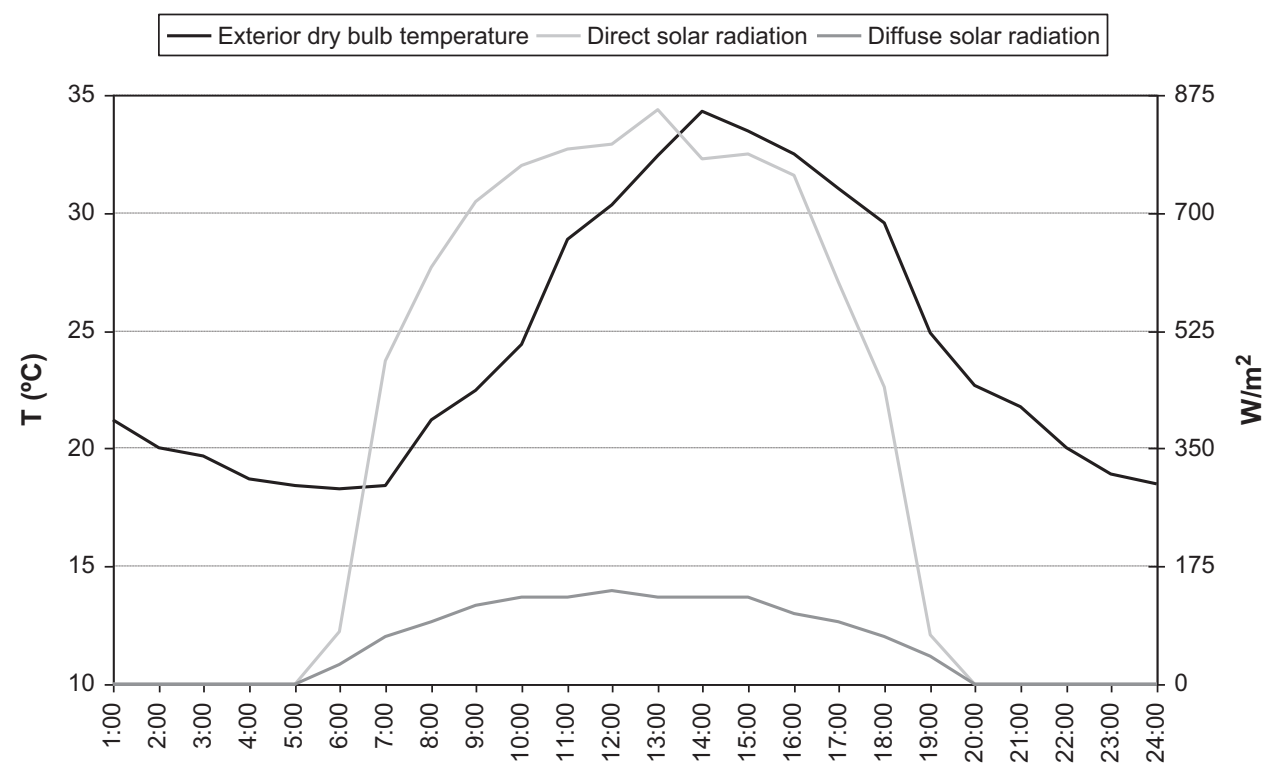

Fig. 13. Outdoor air temperature, direct solar radiation and diffuse solar radiation, August 12th (Coimbra).

Table 10

Simplified economic analysis: Admissible extra cost values for several time periods; EC glass in east facade.

Energy for heating saved by the use of EC glass

Energy for cooling saved by the use of EC glass

Annual energy saved by the use of EC glass

EC glass area

Annual energy saved per unit area

kWh price

(excluding taxes and power rate)

Maximum permissible costs $\left(€ / \mathrm{m}^{2}\right)$ to amortize the investment in EC windows in:

\begin{tabular}{lrl} 
& 39 & $\mathrm{kWh}$ \\
71 & $\mathrm{kWh}$ \\
& 110 & $\mathrm{kWh}$ \\
& 5.4 & $\mathrm{~m}^{2}$ \\
& 20.28 & $\mathrm{kWh} / \mathrm{m}^{2}$ EC glass yr \\
& $0.14 €$ & \\
& & \\
1 year & $2.84 €$ & \\
5 years & $14.19 €$ & \\
10 years & $28.39 €$ & \\
15 years & $42.58 €$ & \\
20 years & $56.78 €$ & \\
\hline
\end{tabular}

Table 11

Simplified economic analysis: Admissible extra cost values for several time periods; EC glass in west facade.

\begin{tabular}{|c|c|c|c|}
\hline Energy for heating saved by the use of EC glass & & 98 & $\mathrm{kWh}$ \\
\hline Energy for cooling saved by the use of EC glass & & 102 & kWh \\
\hline Annual energy saved by the use of EC glass & & 200 & kWh \\
\hline EC glass area & & 5.4 & $\mathrm{~m}^{2}$ \\
\hline Annual energy saved per unit area & & 36.94 & $\mathrm{kWh} / \mathrm{m}^{2} \mathrm{EC}$ glass yr \\
\hline $\begin{array}{l}\text { kWh price } \\
\text { (excluding taxes and power rate) }\end{array}$ & & $0.14 €$ & \\
\hline \multirow[t]{5}{*}{ Maximum permissible costs $\left(€ / \mathrm{m}^{2}\right)$ to amortize the investment in EC windows in: } & 1 year & $5.17 €$ & \\
\hline & 5 years & $25.86 €$ & \\
\hline & 10 years & $51.72 €$ & \\
\hline & 15 years & $77.58 €$ & \\
\hline & 20 years & $103.44 €$ & \\
\hline
\end{tabular}

commercially available EC glass, the other studies usually admitted EC glass prototypes with better physical characteristics not yet commercially available. Also, the studies only calculate the savings for the cooling season, omitting the possible negative effect of the EC glass in the heating season.

\section{Conclusions}

In this work, the comparison between three glazing options (single glass, conventional double glazing and electrochromic glazing) is performed. Through building energy simulation with the ESP-r program the energy needs for heating and cooling are evaluated. The energy savings, regarding the situation of using single glass (baseline), were calculated by difference of the energy requirements for heating, cooling and annual.

The results show advantages of glasses with controllable properties (EC windows) on east and west facades. The best results of the application of EC glass from the energy performance perspective are obtained for the western facade, with a reduction of the annual energy needs of about $62 \%$ higher than for the east facade. For south facades the use of conventional double glazing shows better results in the annual building energy needs and, therefore, the application of EC glass presents no advantage. 
The results also clearly show the advantage of EC glass for the cooling season and suggest that the EC glass may not be useful for the heating season. As the results are mainly valid for the latitude used and Mediterranean climate, specific simulations must be performed using the applicable climate files in order to corroborate or distinguish the conclusion of this work for other climates. Particularly, careful analysis must be taken into account for climates where the energy needs for heating are dominant.

Considering the obtained energy savings of 20.28 and $36.94 \mathrm{kWh} / \mathrm{m}^{2}$ _glass.year for windows in the east/west facades, and a simple payback of 10 years (the usual manufacturers warranty period), the economical attractiveness is achieved if the extra cost is less than $28.39 / 51.72 € / \mathrm{m}^{2}$ glass. Nevertheless, investment decisions should be informed by additional considerations on other types of benefits of the use of EC glass.

It is concluded that the EC glasses are an energy-efficient solution for use in buildings. Nevertheless, the adoption of this technology in rehabilitation strategies of building fenestration should taking into account each facade orientation, giving priority to east and west facades, where the control of solar gains are more difficult. Nevertheless, the present results clearly show that the application of this type of glazing in the rehabilitation of buildings should always be preceded by careful study.

The use of building energy simulation tools that can be adapted to accommodate these types of technological solutions with dynamic properties (e.g. EC glass) are of high importance to help building designers to forecast the influence of such new technological elements for building construction, both in the design phase of new or rehabilitated buildings. In fact, there are nowadays several building energy simulation tools that permit the energy performance comparison of different technological solutions with confidence. Therefore, it is high recommended that the policy makers will require the use of this kind of tools in the national building regulations context.

\section{Acknowledgments}

This work is being developed in the context of the Initiative "Energy for Sustainability" of the University of Coimbra and is supported by the Portuguese "Fundação para a Ciência e a Tecnologia" (FCT-Foundation for Science and Technology) under Contract no. SFRH/BD/35910/2007.

\section{References}

Assimakopoulos, M.N., Tsangrassoulis, A., Santamouris, M., Guarracino, G., 2007. Comparing the energy performance of an electrochromic window under various control strategies. Building and Environment 42, 2829-2834, http: //dx.doi.org/10.1016/j.buildenv.2006.04.004.

Avendaño, E., Berggren, L., Niklasson, G.A., Granqvist, C.G., Azens, A., 2006. Electrochromic materials and devices: brief survey and new data on optical absorption in tungsten oxide and nickel oxide films. Thin Solid Films 496, 30-36, http://dx.doi.org/10.1016/j.tsf.2005.08.183.

Azens, A., Granqvist, C.G., 2003. Electrochromic smart windows: energy efficiency and device aspects. Journal of Solid State Electrochemistry 7, 64-68, http://dx. doi.org/10.1007/s10008-002-0313-4.

Azens, A., Avendaño, E., Backholm, J., Berggren, L., Gustavsson, G., Karmhag, R., Niklasson, G.A., Roos, A., Granqvist, C.G., 2005. Flexible foils with electrochromic coatings: science, technology and applications. Materials Science and Engineering B 119, 214-223, http://dx.doi.org/10.1016/j.mseb.2004.12.085.

Baetens, Ruben, Jelle, Bjørn Petter, Gustavsen, Arild, 2010. Properties, requirements and possibilities of smart windows for dynamic daylight and solar energy control in buildings: a state-of-the-art review. Solar Energy Materials and Solar Cells 94, 87-105, http://dx.doi.org/10.1016/j.solmat.2009.08.021.

Carmody, John, Selkowitz, Stephen, Lee, Eleanor S., Arasteh, Dariush Willmert, Todd, 2004. Window Systems for High-Performance Buildings. W.W. Norton and Company, Inc., ISBN: 0-393-73121-9.

Clarke, Joseph A., 2001. Energy Simulation in Building Design (2nd edition). Butterworth-Heinemann, ISBN: 0-7506-5082-6.

Crawley, Drury B., Hand, Jon W., Kummert, Michaël Griffith, Brent T., 2005a. Contrasting the capabilities of building energy performance simulation programs. Report, Version 1.0, made following a joint effort of the Department of Energy of the United States of America, the University of Wisconsin and the University of Strathclyde. Available from: 〈http://apps1.eere.energy.gov/build ings/tools_directory/pdfs/contrasting_the_capabilities_of_building_energy_per formance_simulation_programs_v1.0.pdf $\rangle$.

Crawley, Drury B., Hand, Jon W., Kummert, Michaël Griffith, Brent, T., 2005b. Contrasting the Capabilities of Building Energy Performance Simulation Programs. In: Proceedings of Building Simulation 2005, Ninth International IBPSA Conference, Montréal, Canadá, 15th-18th August 2005.

Crawley, Drury B., Hand, Jon W., Kummert, Michaël Griffith, Brent, T., 2008. Contrasting the capabilities of building energy performance simulation programs. Building and Environment 43, 661-673, http://dx.doi.org/10.1016/j. buildenv.2006.10.027.

Fasano, G., Maccari, A., Polato, P., Zinzi, M.,2002. A detailed characterization of commercial electrochromic devices for building applications. In: Proceedings of EUROSUN 2002, Bologna, Italy, 23-26 June 2002.

Frontini, Francesco, Kuhn, Tilmann E., Herkel, Sebastian, Strachan, Paul Kokogiannakis, Georgios, 2009. Implementation and applications of a new bi-directional solar modelling method for complex facades within the ESP-r building simulation program. In: Proceedings of Eleventh International IBPSA Conference, Building Simulation 2009, Glasgow, Scotland, 27-30 July 2009.

Granqvist, C.G., 2000. Electrochromic tungsten oxide films: review of progress 1993-1998. Solar Energy Materials and Solar Cells 60, 201-262, http://dx.doi org/10.1016/S0927-0248(99)00088-4.

Granqvist, C.G., 2001. Electrochromic smart windows: toward an energy efficient architecture. Electrochemical Society Interface 18-19, 2001. (Fall).

Granqvist, C.G., 2005. Electrochromic devices. Journal of the European Ceramic Society 25, 2907-2912, http://dx.doi.org/10.1016/j.jeurceramsoc.2005.03.162.

Granqvist, C.G., 2006a. Electrochromic materials: out of a niche. Nature Materials 5 89-90.

Granqvist, C.G., 2006b. Electrochromics: finally a technology for large-scale applications. SPIE Newsroom: International Society for Optical Engineering http://dx.doi.org/10.1117/2.1200602.0140.

Granqvist, C.G., 2007. Transparent conductors as solar energy materials: a panoramic review. Solar Energy Materials and Solar Cells 91, 1529-1598, http://dx.doi. org/10.1016/j.solmat.2007.04.031.

Granqvist, C.G., 2008. Oxide electrochromics: Why, how, and whither. Solar Energy Materials \& Solar Cells 92, 203-208, http://dx.doi.org/10.1016/j. solmat.2006.10.027.

Granqvist, C.G., 2012. Oxide electrochromics: an introduction to devices and materials. Solar Energy Materials and Solar Cells 99, 1-13, http://dx.doi.org 10.1016/j.solmat.2011.08.021.

Granqvist, C.G., Avendaño, E., Azens, A., 2003. Electrochromic coatings and devices: survey of some recent advances. Thin Solid Films 442, 201-211, http://dx.doi. org/10.1016/S0040-6090(03)00983-0.

Granqvist, C.G., Azens, A., Smulko, J., Kish, L.B., 2007. Oxide-based electrochromics for energy efficient buildings: Materials, technologies, testing, and perspectives. Journal of Physics: Conference Series 93. (doi: 10.1088/1742-6596/93/1/012021).

Granqvist, C.G., Green, S., Niklasson, G.A., Mlyuka, N.R., von Kræmer, S., Georén, P., 2010. Advances in chromogenic materials and devices. Thin Solid Films 518, 3046-3053, http://dx.doi.org/10.1016/j.tsf.2009.08.058.

Granqvist, C.G., Lansaker, P.C., Mlyuka, N.R., Niklasson, G.A., Avendaño, E., 2009. Progress in chromogenics: new results for electrochromic and thermochromic materials and devices. Solar Energy Materials and Solar Cells 93, 2032-2039, http://dx.doi.org/10.1016/j.solmat.2009.02.026.

Haugaard, Per, 2003. Investigation and implementation of building simulation programmes: especially ESP-r. Masters Dissertation, Technical University of Denmark. (Denmark).

Häusler, T.; Fischer, U.; Rottmann, M.; Kraft, A. Heckner, K.-H., 2004. Solar optical properties and daylight potential of electrochromic windows. In: Proceedings of World Renewable Energy Congress VIII, Denver, USA, August 29 to September 3, 2004.

Jonsson, Andreas, Roos, Arne, 2010a. Evaluation of control strategies for different smart window combinations using computer simulations. Solar Energy 84, 1-9, http://dx.doi.org/10.1016/j.solener.2009.10.021.

Jonsson, Andreas, Roos, Arne, 2010b. Visual and energy performance of switchable windows with antireflection coatings. Solar Energy 84, 1370-1375, http://dx doi.org/10.1016/j.solener.2010.04.016.

Karlsson, J., 2001. Control system and energy saving potential for switchable windows. In: Proceedings of 7th International IBPSA Conference, Rio de Janeiro, Brasil, 13-15 August, 2001.

Karlsson, J., Roos, A., 2000. Modelling the angular behaviour of the total solar energy transmittance of windows. Solar Energy 69 (4), 321-329.

Karlsson, J., Rubin, M., Roos, A., 2001. Evaluation of predictive models for the angledependent total solar energy transmittance of glazing materials. Solar Energy 71 23-31.

Kraft, Alexander, Rottmann, Matthias, 2006. Electrochromic safety glass for smartwindow applications. SPIE Newsroom: International Society for Optical Engineering. 10.1117/2.1200603.0196.

Kraft, Alexander, Rottmann, Matthias, 2009. Properties, performance and current status of the laminated electrochromic glass of Gesimat. Solar Energy Materials and Solar Cells 93, 2088-2092, http://dx.doi.org/10.1016/j.solmat.2009.05.010.

Kraft, Alexander, Rottmann, Matthias, Heckner, Karl-Heinz, 2006. Large-area electrochromic glazing with ion-conducting PVB interlayer and two complementary electrodeposited electrochromic layers. Solar Energy Materials and Solar Cells 90, 469-476, http://dx.doi.org/10.1016/j.solmat.2005.01.019. 
Kuhn, Tilmann E., 2006. Solar control: a general evaluation method for facades with Venetian blinds or other solar control systems. Energy and Buildings 38, 648-660, http://dx.doi.org/10.1016/j.enbuild.2005.10.002.

Kuhn, Tilmann, Herkel, E.Sebastian, Frontini, Francesco, Strachan, Paul, Kokogiannakis, Georgios, 2011. Solar control: a general method for modelling of solar gains through complex facades in building simulation programs. Energy and Buildings 43, 19-27, http://dx.doi.org/10.1016/j.enbuild.2010.07.015.

Lee, E.S., DiBartolomeo, D.L., 2002. Application issues for large-area electrochromic windows in commercial buildings. Solar Energy Materials and Solar Cells 71, 465-491, http://dx.doi.org/10.1016/S0927-0248(01)00101-5.

Lee, E.S., DiBartolomeo, D.L., Rubinstein, F.M., Selkowitz, S.E., 2004. Low-cost networking for dynamic window systems. Energy and Buildings 36, 503-513. http://dx.doi.org/10.1016/j.enbuild.2003.12.008.

Mortimer, Roger J., Dyer, Aubrey L., Reynolds, John R., 2006. Electrochromic organic and polymeric materials for display applications. Displays $27,2-18$, http://dx. doi.org/10.1016/j.displa.2005.03.003.

Niklasson, G.A., Granqvist, C.G., 2007. Electrochromics for smart windows: thin films of tungsten oxide and nickel oxide, and devices based on these. Journal of Materials Chemistry 17, 127-156, http://dx.doi.org/10.1039/b612174h.

Papaefthimiou, S., Leftheriotis, G., Yianoulis, P., Hyde, T.J., Eames, P.C., Fang, Y. Pennarun, P.-Y., Jannasch, P., 2006a. Development of electrochromic evacuated advanced glazing. Energy and Buildings 38, 1455-1467, http://dx.doi.org/ 10.1016/j.enbuild.2006.03.029.

Papaefthimiou, S., Syrrakou, E., Yianoulis, P., 2006b. Energy performance assessment of an electrochromic window. Thin Solid Films 502, 257-264, http://dx. doi.org/10.1016/j.tsf.2005.07.294.

Piccolo, A., Pennisi, A., Simone, F., 2009. Daylighting performance of an electrochromic window in a small scale test-cell. Solar Energy 83, 832-844, http://dx doi.org/10.1016/j.solener.2008.11.013.

Platzer, W.J., 2000. The ALTSET Project: measurement of angular properties for complex glazing. In: Proceedings of EuroSun 2000 Conference, Copenhagen, Denmark, 19-22 July, 2000

Rauh, R.David, 1999. Electrochromic windows: an overview. Electrochimica Acta 44, 3165-3176, http://dx.doi.org/10.1016/S0013-4686(99)00034-1.

Roos, Arne, Karisson, Joakim, van Nijnatten, Peter A., Hutchins, Michael G., Polato, Pietro, Nichelatti, Enrico, Montecchi, Marco, Olive, Francois, Anderson, Charles, 2001. Angular dependent optical properties of coated glazings: validation of two predictive algorithms. Solar and Switching Materials, Proceedings of SPIE $4458,19-28$

Roos, Arne, Persson, Mari-Louise, Platzer, Werner, Köhl, Michael, 2005. Energy efficiency of switchable glazing in office buildings. In: Proceedings of Glass Processing Days 2005, 9th International Glass Conference, Tampere, Finland, 17-20 June, 2005.

Roos, Arne, Polato, Pietro, Van Nijnatten, Peter A, Hutchins, Michael G, Olive, Francois, Anderson, Charles, 2000. Angular-dependent optical properties of low-e and solar control windows: simulations versus measurements. Solar Energy 69 (Suppls. 1-6), 15-26.

Rosenfeld, J.L.J., 1996. On the calculation of the total solar energy transmittance of complex glazings. In: Proceedings of the 8th International Meeting on Transparent Insulation Material, Freiburg, Germany, 1996.

Rosenfeld, J.L.J., Platzer, W.J., van Dijk, H., Maccari, A., 2000. Modelling the optical and thermal properties of advanced glazing: overview of recent developments. In: Proceedings of EuroSun 2000 Conference, Copenhagen, Denmark, 19-22 June, 2000.

Rowley, Natalie M., Mortimer, Roger J., 2002. New electrochromic materials. Science Progress 85 (3), 243-262.

RSECE, 2006. Regulamento dos sistemas energéticos de climatização em edifícios. Decreto-Lei no. 79/2006 de 4 de abril de 2006 (in Portuguese)

Sanders, H., Podbelski, L., 2009. Electronically tintable glass: the future of high performance facades is here. In: Proceedings of Glass Performance Days 2009, Architectural Challenges and Solutions, Tampere, Finland, 12-15 June, 2009.

Sanders, Helen, 2010. Getting to net zero energy buildings with electronically tintable glass. Verre 16 (4), 42-47.

Sanders, Helen E., Podbelski, Louis, 2010. Electronically tintable glass: The future of high performance façades is here. In: Proceedings of "Engineered transparency - International Conference at glasstec", Düsseldorf (Germany), 29-30 September 2010.

Santamouris, M., Dascalaki, E., 2002. Passive retrofitting of office buildings to improve their energy performance and indoor environment: the OFFICE project. Building and Environment 37, 575-578.

Somani, Prakash R., Radhakrishnan, S., 2002. Electrochromic materials and devices: present and future. Materials Chemistry and Physics 77, 117-133.

Sottile, Gregory M., 2002. Assessment of attitudes and expectations of switchable glass among United States window manufacturers. In: Proceedings of 45th Annual Technical Conference, Society of Vacuum Coaters, Lake Buena Vista, FL, USA, 13-18 April, 2002.

Stenzel, Holger, Kraft, Alexander, Heckner, Karl-Heinz, Rottmann, Matthias, Steuer, Martin, Papenfuhs, Bernd, 2003. Electrochromic glazing with an ion-conducting pvb interlayer. In: Proceedings of Glass Processing Days 2003, 8th International Glass Conference, Tampere, Finland, 15-18 June, 2003.

Strachan, Paul, 1990. Addition of blinds/shutter control to transparent multi-layer constructions and other improvements to the solar routines of ESPsim. 〈http://www.esru.strath.ac.uk/Documents/90/strachan_solar_mods.pdf〉 (accessed 15.04.09).

Syrrakou, E., Papaefthimiou, S., Skarpentzos, N., Yianoulis, P., 2005. Electrochromic windows: physical characteristics and environmental profile. Ionics 11, 281-288, http://dx.doi.org/10.1007/BF02430390.

Syrrakou, E., Papaefthimiou, S., Yianoulis, P., 2006. Eco-efficiency evaluation of a smart window prototype. Science of the Total Environment 359, 267-282, http: //dx.doi.org/10.1016/j.scitotenv.2005.10.023. 